\title{
Carbon dioxide balance of subarctic tundra from plot to regional scales
}

\author{
M. E. Marushchak ${ }^{1,3}$, I. Kiepe ${ }^{2}$, C. Biasi ${ }^{1}$, V. Elsakov ${ }^{3}$, T. Friborg ${ }^{2}$, T. Johansson ${ }^{2}$, H. Soegaard ${ }^{2}$, T. Virtanen ${ }^{4}$, and \\ P. J. Martikainen ${ }^{1}$ \\ ${ }^{1}$ Department of Environmental Science, University of Eastern Finland, P.O. Box 1627, 70211 Kuopio, Finland \\ ${ }^{2}$ Department of Geography \& Geology, University of Copenhagen, Øster Voldgade 10, 1350 Copenhagen K, Denmark \\ ${ }^{3}$ Institute of Biology, Komi SC UrD RAS, 167982 Syktyvkar, Russia \\ ${ }^{4}$ Department of Environmental Sciences, University of Helsinki, P.O. Box 27, 00014 University of Helsinki, Finland
}

Correspondence to: M. E. Marushchak (maija.marushchak@uef.fi)

Received: 25 June 2012 - Published in Biogeosciences Discuss.: 1 August 2012

Revised: 10 December 2012 - Accepted: 18 December 2012 - Published: 24 January 2013

\begin{abstract}
We report here the carbon dioxide $\left(\mathrm{CO}_{2}\right)$ budget of a $98.6 \mathrm{~km}^{2}$ subarctic tundra area in northeast European Russia based on measurements at two different scales and two independent upscaling approaches. Plot-scale measurements (chambers on terrestrial surfaces, gas gradient method and bubble collectors on lakes) were carried out from July 2007 to October 2008. The landscape-scale eddy covariance (EC) measurements covered the snow-free period of 2008. The annual net ecosystem exchange (NEE) of different land cover types ranged from -251 to $84 \mathrm{~g} \mathrm{C} \mathrm{m}^{-2}$. Leaf area index (LAI) was an excellent predictor of the spatial variability in gross photosynthesis (GP), NEE and ecosystem respiration (ER). The plot-scale $\mathrm{CO}_{2}$ fluxes were first scaled up to the EC source area and then to the whole study area using two data sets: a land cover classification and a LAI map, both based on field data and a $2.4 \mathrm{~m}$ pixel-sized QuickBird satellite image. The good agreement of the $\mathrm{CO}_{2}$ balances for the $\mathrm{EC}$ footprint based on the different measuring techniques ( -105 to $-81 \mathrm{~g} \mathrm{C} \mathrm{m}^{-2}$ vs. $-79 \mathrm{~g} \mathrm{C} \mathrm{m}^{-2}$; growing season 2008) justified the integration of the plot-scale measurements over the larger area. The regional $\mathrm{CO}_{2}$ balance based on area-integrated plot-scale measurements was -41 or $-79 \mathrm{~g} \mathrm{C} \mathrm{m}^{-2} \mathrm{yr}^{-1}$ according to the two upscaling methods, the land cover classification and the LAI map, respectively. Due to the heterogeneity of tundra, the effect of climate change on $\mathrm{CO}_{2}$ uptake will vary strongly according to the land cover type and, moreover, likely changes in their relative coverage in the future will have great impact on the regional $\mathrm{CO}_{2}$ balance.
\end{abstract}

\section{Introduction}

The strong warming predicted for the Arctic by global climate models (Kattsov et al., 2005) has underlined the need to understand how carbon $(\mathrm{C})$ fluxes in tundra will respond to climate change. Carbon storage in plant biomass is low in the Arctic (Bazilevich, 1993; Hugelius et al., 2011), but northern permafrost soils contain as much as $50 \%$ of global belowground soil C pool (Tarnocai et al., 2009). There, higher temperatures and permafrost thaw will likely enhance the mineralization of soil organic matter in the future, thereby increasing release of $\mathrm{C}$ as carbon dioxide $\left(\mathrm{CO}_{2}\right)$ to the atmosphere (Dorrepaal et al., 2009; Schuur et al., 2009). At the same time, there will be changes in vegetation composition and productivity (Walker et al., 2006; Forbes et al., 2010). The increase in above-ground $\mathrm{C}$ stocks may partly compensate for the respiratory below-ground $\mathrm{C}$ losses, at least in the short term (Qian et al., 2010).

In order to predict the changes in the tundra $\mathrm{C}$ balance in the future, we need to accurately estimate the present-day $\mathrm{C}$ balance and understand its dependence on environmental factors. This is a real challenge, taking into account the high temporal (e.g., Kwon et al., 2006; Groendahl et al., 2007) and spatial (e.g., Heikkinen et al., 2004; Fox et al., 2008) variability of $\mathrm{CO}_{2}$ fluxes in tundra, as well as the logistical difficulties when working in remote areas. Studies on tundra $\mathrm{CO}_{2}$ exchange have been previously conducted using either the micrometeorological eddy covariance (EC) method (e.g., Moncrieff et al., 1997; Nordstroem et al., 2001; Corradi et 

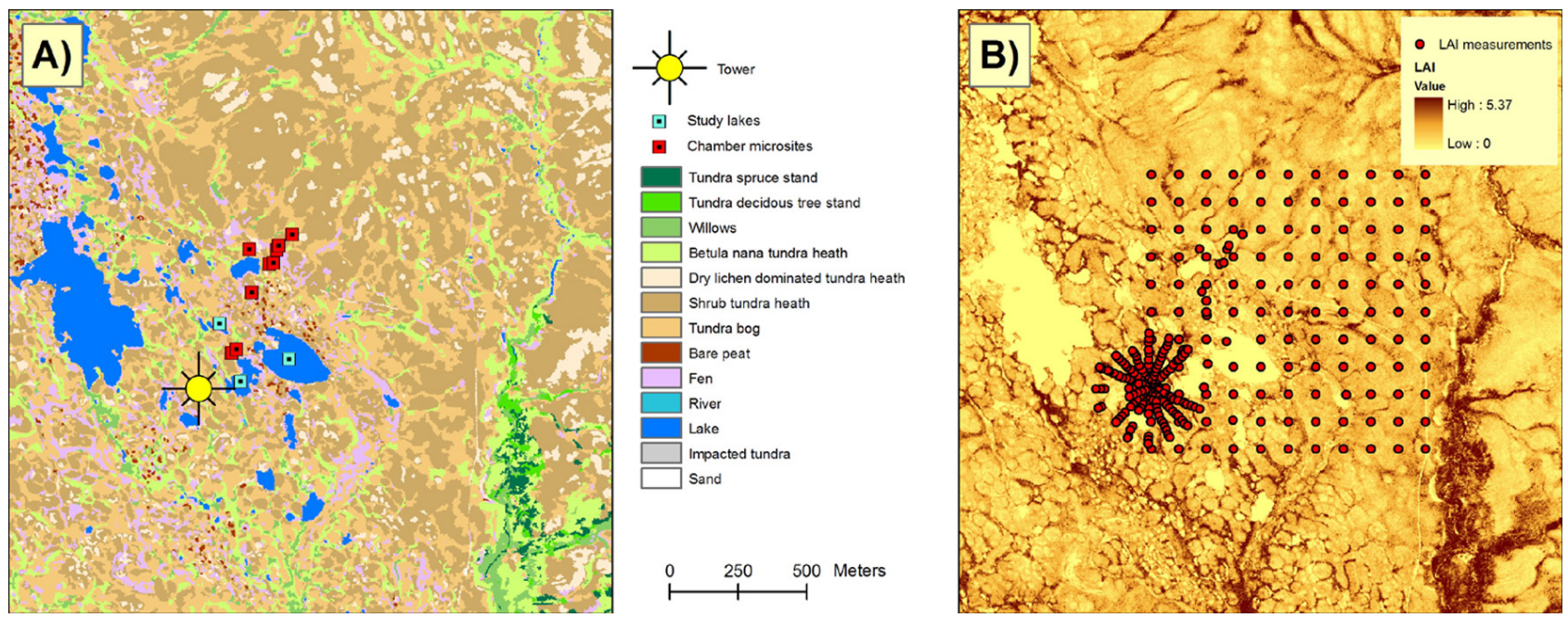

Fig. 1. (A) Land cover classification of the study area. Location of the eddy covariance mast, chamber microsites and thermokarst lakes studied are shown on the map. (B) LAI map, showing the location of the LAI ground measurements.

al., 2005; Kutzbach et al., 2007b; Lafleur and Humphreys, 2008; Humphreys and Lafleur, 2011; Parmentier et al., 2011; Lund et al., 2012) or chamber techniques (e.g., Christensen et al., 2000; Heikkinen et al., 2002, 2004; Shaver et al., 1998, 2007). Although the EC and chamber methods are complementary of each other, there are only few studies where these two techniques have been applied in parallel in order to study $\mathrm{CO}_{2}$ exchange in tundra (Soegaard et al., 2003; Zamolodchikov et al., 2003; Fox et al., 2008).

With high-frequency micrometeorological EC measurements it is possible to get continuous data set over a source area of $0.1-1 \mathrm{~km}^{2}$ and catch the short-term variations in gas fluxes often missed by (manual) chambers (e.g., Pihlatie et al., 2010). On the other hand, chamber measurements give information on spatial variability in fluxes of different functional ecosystem types, often located at short distances in tundra landscape. This kind of data provides good grounds for extrapolating, or "upscaling" fluxes to a regional scale. However, upscaling based on chambers can be risky if the measuring frequency is low or the distribution of various surfaces is not well documented. Chamber measurements can also cause disturbance to the studied system and, thus, affect the gas flux rates observed (e.g., Kutzbach et al., 2007a). In the upscaling process, comparison of EC results and plotscale measurements in the EC source area serves as an intermediate step towards extrapolation to larger scale, making the regional estimates scientifically sound.

Due to the fragmented nature of tundra environment, it is critical to select a relevant spatial scale for upscaling efforts. Landsat satellite data with $30 \mathrm{~m}$ resolution, used in most studies on regional $\mathrm{CO}_{2}$ balance of tundra (Soegaard et al., 2003; Heikkinen et al., 2004), are not detailed enough to detect the small scale differences typical for tundra (Laidler and Treitz, 2003). The first remote sensing studies on Arctic vege- tation using higher resolution than Landsat satellite images have been conducted only recently (Fuchs et al., 2009). In the present study, we use a land cover classification based on QuickBird imagery with $2.4 \mathrm{~m}$ resolution, appropriate for detecting the relevant spatial variability of the landscape investigated.

In this study, we aimed at quantifying $\mathrm{CO}_{2}$ fluxes in a tundra landscape and investigating the controlling factors, in order to provide a sound basis for upscaling the fluxes to the regional level. The study was conducted in discontinuous permafrost region in Komi Republic, northern European Russia. We measured the $\mathrm{CO}_{2}$ exchange over a whole snow-free period at two different scales: the chamber technique in terrestrial surfaces and the gas gradient method and bubble traps in lakes (plot scale), and the EC method (landscape scale). The results of these methods were compared in the EC source area using the footprint analysis. Plot-scale measurements, conducted over a prolonged period (two summers and one winter), give insights to the inter- and intra-annual variability in $\mathrm{CO}_{2}$ exchange. The final goal was to estimate the $\mathrm{CO}_{2}$ balance for a region of $98.6 \mathrm{~km}^{2}$ based on the fluxes of different land cover types that were scaled up using two alternative methods. The upscaling methods were based on two high-resolution satellite derived data sets, a land cover classification and a leaf area index (LAI) map.

\section{Methods}

\subsection{Study site}

The study site, near the settlement Seida, is located in southern tundra with discontinuous permafrost in northeast European Russia $\left(67^{\circ} 03^{\prime} \mathrm{N}, 62^{\circ} 56^{\prime} \mathrm{E}\right)$. The mean air temperature in the region is $-5.6^{\circ} \mathrm{C}$ and the mean annual precipitation 
$501 \mathrm{~mm}$. Monthly mean values are found in Table 1 (longterm averages for 1977-2006, data from Vorkuta station $\left(67^{\circ} 48^{\prime} \mathrm{N}, 64^{\circ} 01^{\prime} \mathrm{E}, 172 \mathrm{~m}\right.$ a.s.1.); Komi Republican Center for Hydrometeorological and Environmental Monitoring).

Most of the landscape in the region is hilly upland with tundra heath vegetation ("upland tundra"; coverage $58 \%$ based on a land cover classification described in Sect. 2.5.1) dominated by shrub-lichen-moss communities (Table 2). Also, peatlands with bog vegetation are typical for the region ("dry peatlands"; coverage $24 \%$ ). These peatlands include peat plateaus with up to several meters thick peat deposits, raised up by permafrost. The peat plateaus are spotted by unvegetated patterned ground features ("bare peat") and small thermokarst lakes ("lakes"). Narrow fens and willow stands ("wetlands"; $14 \%$ ) are located on low-lying parts of the landscape that act as water conduits in the terrain. The abovementioned land cover types, all studied at plot scale (Table 2), represent $97 \%$ of the landscape. The residual landscape area ( $3 \%$ ) is covered by deciduous and coniferous forest stands, rivers, human-impacted tundra and sand. The terrestrial microsites and lakes studied at plot scale were located within the EC footprint area northeast from the EC tower (Fig. 1a). More details on the soils and vegetation at the Seida study site are provided by Hugelius et al. (2011) and Marushchak et al. (2011).

\subsection{Auxiliary data}

Auxiliary data were collected on air temperature, soil heat flux, net radiation, photosynthetically active radiation (PAR), precipitation, wind speed and wind direction by a weather station located at the study site. Parameters showing large heterogeneity across the landscape, such as soil moisture $\left(\theta_{v}\right)$, soil temperature, groundwater level and active layer depth, were monitored on various land cover types. The leaf area index of vascular plants (LAI) was measured in JuneSeptember 2008 at 284 field measurement points (Fig. 1b). More details on auxiliary data collection are available in the Supplement.

\subsection{Carbon dioxide exchange at plot scale}

\subsubsection{Chamber measurements at terrestrial microsites}

Exchange of $\mathrm{CO}_{2}$ was measured at the terrestrial microsites with a closed chamber technique (Heikkinen et al., 2002) in July-October 2007 and May-October 2008 (Table 2). Measurements were carried out mainly between 08:00 a.m. and 09:00 p.m. using a transparent polycarbonate chamber $(30 \times 60 \times 60 \mathrm{~cm})$ with an infrared gas analyzer (Li-840, LiCor). The chamber had a cooling unit with ice water circulation that kept the temperature in the chamber headspace close to the ambient. Data on $\mathrm{CO}_{2}$ concentration, air temperature inside and outside the chamber (107 Thermistor Probe
C/W, Campbell Scientific, UK) and PAR (SKP215, Skye Instruments, UK) were collected to a data logger (CR850, Campbell Scientific) at 2-s intervals during 2-min measurements.

Net ecosystem $\mathrm{CO}_{2}$ exchange (NEE) measurements were done in ambient and reduced light conditions ( $~ 50 \%$ PAR), created by shadowing the chamber with a net. For measuring ecosystem respiration (ER), the chamber was darkened with an aluminum lid. Each microsite had 3 replicate soil collars (depth $15 \mathrm{~cm}$ ) that served as permanent measurement plots. At the willow site additional collars (height $60 \mathrm{~cm}$ ) were used during the $\mathrm{CO}_{2}$ flux measurements.

Carbon dioxide fluxes were calculated from the increase in $\mathrm{CO}_{2}$ concentration in the chamber headspace using an exponential non-linear model by Kutzbach et al. (2007a) in MATLAB (R2008a) program. Residual standard deviation of the regression $>1.5 \mathrm{ppm}$ was used as a filtering criterion, based on which $2 \%$ of the flux data were rejected. Gross photosynthesis (GP) was calculated as a difference between consecutive NEE and ER measurements. We follow a sign convention where $\mathrm{C}$ loss from the ecosystem is defined as positive and $\mathrm{C}$ uptake as negative values.

\subsubsection{Interpolating gross photosynthesis and ecosystem respiration over time}

The two components of net $\mathrm{CO}_{2}$ flux, GP and ER, were interpolated over the measuring period based on their dependence on environmental parameters using non-linear regression in SPSS 14.0 statistical software (Table 3). Response functions for ER were formulated individually for each chamber plot, while parameterization of the more complex GP functions was done at the microsite level $(n=3)$. Data were split by years, and for GP growing season 2008 was further divided into early and late season. The GP models included a Michaelis-Menten type equation for the light response, a Gaussian or linear temperature term and a linear LAI term. The LAI data from 2008 were used also for 2007, which was justified by the good model fit in 2007. For surfaces without any vascular plants ("bare peat") a soil moisture term was used instead of the LAI term. Ecosystem respiration was described with an Arrhenius-type temperature dependence (Lloyd and Taylor, 1994). Anomalously high respiration peaks at soil freezing and thawing ( $2 \%$ of all data) were removed before the modeling (Supplement Fig. S1).

\subsection{Carbon dioxide fluxes during snow period}

During the snow period $\mathrm{CO}_{2}$ fluxes were measured with a snow-gradient method as described by Marushchak et al. (2011). Fluxes were determined in January-June 2008 a total 2-5 times per plot depending the timing of the snow melt. The samples were stored in glass vials a maximum of three months before analysis on a gas chromatograph (HP 5890 series II, Hewlett-Packard, USA) with a thermal 
Table 1. Monthly mean air temperatures and precipitation in 2007-2008 and long-term mean \pm SD at Vorkuta meteorological station $\left(67^{\circ} 48^{\prime} \mathrm{N}, 64^{\circ} 01^{\prime} \mathrm{E}, 172 \mathrm{~m}\right.$ a.s.l.). Data from Komi Republican Center for Hydrometeorological and Environmental Monitoring. Monthly values significantly differing from the long-term means are shown in bold.

\begin{tabular}{lrrrrrrrrrrrrr}
\hline & Jan & Feb & Mar & Apr & May & Jun & Jul & Aug & Sep & Oct & Nov & Dec & Annual \\
\hline Air $T\left({ }^{\circ} \mathrm{C}\right)$ & & & & & & & & & & & \\
\hline 2007 & $\mathbf{- 1 1 . 5}$ & -23.6 & $\mathbf{- 1 0 . 0}$ & $\mathbf{- 3 . 6}$ & -3.5 & 8.2 & $\mathbf{1 7 . 8}$ & 9.3 & 5.4 & $\mathbf{0 . 8}$ & -10.0 & $\mathbf{- 1 2 . 6}$ & $\mathbf{- 2 . 8}$ \\
2008 & $\mathbf{- 1 1 . 6}$ & -17.6 & -15.0 & -11.4 & -3.2 & 7.4 & $\mathbf{1 5 . 6}$ & 9.4 & 4.8 & -0.7 & -10.9 & $-\mathbf{1 0 . 7}$ & $-\mathbf{3 . 7}$ \\
$1977-2006$ & -20.4 & -19.9 & -14.4 & -10.4 & -1.7 & 7.5 & 13.0 & 9.6 & 4.2 & -4.2 & -13.1 & -17.8 & -5.6 \\
& \pm 4.7 & \pm 4.9 & \pm 3.6 & \pm 4.6 & \pm 2.6 & \pm 2.7 & \pm 2.2 & \pm 2.0 & \pm 1.7 & \pm 3.2 & \pm 4.8 & \pm 4.2 & \pm 1.4 \\
\hline \multirow{2}{*}{ Rain (mm) } & & & & & & & & & & & & \\
\hline 2007 & 32 & 13 & 35 & 39 & 29 & 66 & 30 & 62 & 61 & $\mathbf{8 9}$ & 33 & n.a. & n.a. \\
$2008^{*}$ & n.a. & n.a. & n.a. & n.a. & n.a. & $\mathbf{1 2}$ & 53 & 59 & 42 & n.a. & n.a. & n.a. & n.a. \\
$1977-2006$ & 34 & 36 & 28 & 30 & 37 & 55 & 55 & 60 & 55 & 58 & 40 & 42 & 501 \\
& \pm 14 & \pm 19 & \pm 12 & \pm 17 & \pm 12 & \pm 25 & \pm 26 & \pm 30 & \pm 30 & \pm 20 & \pm 13 & \pm 15 & \pm 110 \\
\hline
\end{tabular}

* Precipitation as liquid rain measured at the study site.

Table 2. Coverage of different land cover types in the study region and their correspondence to microsites measured at plot scale (chamber, snow gradient and lake measurements). The percent coverage of each land cover type and microsite is shown for the $98.6 \mathrm{~km}^{2}$ QuickBird area.

\begin{tabular}{|c|c|c|c|}
\hline Land cover types & $\begin{array}{r}\text { Coverage } \\
(\%)\end{array}$ & Microsites studied at plot scale & $\begin{array}{r}\text { Coverage } \\
(\%)\end{array}$ \\
\hline \multirow{2}{*}{ Shrub tundra heath $(n=6)$} & \multirow{2}{*}{35.7} & Shrub tundra heath, dry $(n=3)$ & 20.2 \\
\hline & & Shrub tundra heath, moist $(n=3)$ & 15.4 \\
\hline Betula nana tundra heath $(n=3)$ & 15.2 & Betula nana tundra heath $(n=3)$ & 15.2 \\
\hline Dry lichen tundra heath $(n=3)$ & 7.1 & Dry lichen tundra heath $(n=3)$ & 7.1 \\
\hline Upland tundra $(n=12)$ & Total 57.9 & & \\
\hline \multirow{2}{*}{ Tundra bog $(n=6)$} & \multirow{2}{*}{23.3} & Tundra bog, dry $(n=3)$ & 15.0 \\
\hline & & Tundra bog, moist $(n=3)$ & 8.3 \\
\hline Bare peat $(n=3)$ & 0.3 & Bare peat $(n=3)$ & 0.3 \\
\hline Dry peatlands $(n=9)$ & Total 23.6 & & \\
\hline Willow $(n=3)$ & 8.7 & Willow $(n=3)$ & 8.7 \\
\hline \multirow{2}{*}{ Fen $(n=6)$} & \multirow{2}{*}{5.7} & Fen, Carex dominated $(n=3)$ & 5.1 \\
\hline & & Fen, Eriophorum dominated $(n=3)$ & 0.6 \\
\hline Wetlands $(n=9)$ & Total 14.4 & & \\
\hline Lakes $(n=3)$ & 1.1 & Lakes $(n=3)$ & 1.1 \\
\hline Rivers & 0.3 & n.m. & \\
\hline Water bodies & Total 1.4 & & \\
\hline Deciduous forest stand & 1.2 & n.m. & \\
\hline Spruce forest stand & 1.1 & n.m. & \\
\hline Human-impacted tundra & 0.3 & n.m. & \\
\hline Sand & 0.2 & n.m. & \\
\hline Other classes & Total 2.7 & & \\
\hline TOTAL & 100 & TOTAL & 96.9 \\
\hline
\end{tabular}

$n=$ number of replicate flux measurement plots within land cover type or microsite.

n.m. $=$ not measured

conductivity (TC) detector for $\mathrm{CO}_{2}$ (Nykänen et al., 1995). A leakage test with a gas standard $(2500 \mathrm{ppm})$ showed that the reduction of $\mathrm{CO}_{2}$ concentration in the sample vials over two months was $\leq 3 \%$ (data not shown).

\subsubsection{Carbon dioxide fluxes from lakes}

Emission of $\mathrm{CO}_{2}$ by diffusion and ebullition pathways was studied in three thermokarst lakes from July to August 2007 (11 samplings) and from June to October 2008 (19 samplings). The determination of $\mathrm{CO}_{2}$ concentrations in the surface water and flux calculation using the thin boundary layer 
Table 3. Summary of response functions used for obtaining hourly gross photosynthesis (GP) and ecosystem respiration (ER) values for the three main land cover types; $\mathrm{df}=$ degrees of freedom, $r^{2}=$ coefficient of determination, RMSE = root-mean-square error. Response functions were formulated individually for each microsite (GP) or chamber plot (ER). See Supplement for more details.

\begin{tabular}{|c|c|c|c|c|c|c|c|c|c|c|c|}
\hline & \multirow[b]{2}{*}{$\begin{array}{l}\text { Land cover } \\
\text { types }\end{array}$} & \multicolumn{5}{|c|}{ GP model } & \multicolumn{5}{|c|}{ ER model } \\
\hline & & Period & Function* & df & $r^{2}$ & RMSE & Period & Function* & $\mathrm{df}$ & $r^{2}$ & RMSE \\
\hline Upland tundra & $\begin{array}{l}\text { Shrub tundra } \\
\text { heath, }\end{array}$ & 2007 & 1 & $58-95$ & 0.846 & 0.80 & 2007 & 5 & $30-37$ & 0.607 & 0.64 \\
\hline$n=12$ & $\begin{array}{l}\text { Betula nana } \\
\text { tundra heath, } \\
\text { Dry lichen } \\
\text { tundra heath }\end{array}$ & $\begin{array}{l}\text { May-Jul } 2008 \\
\text { Aug-Oct } 2008\end{array}$ & 1,3 & $\begin{array}{l}77-87 \\
58-71\end{array}$ & 0.810 & $\begin{array}{l}1.08 \\
0.75\end{array}$ & 2008 & 5 & $35-40$ & 0.760 & 0.42 \\
\hline $\begin{array}{l}\text { Dry peatlands } \\
n=9\end{array}$ & $\begin{array}{l}\text { Tundra bog, } \\
\text { Bare peat }\end{array}$ & $\begin{array}{l}2007 \\
\text { May-Jul } 2008 \\
\text { Aug-Oct } 2008\end{array}$ & $\begin{array}{r}1,4 \\
1,3,4 \\
1,4\end{array}$ & $\begin{array}{r}69-101 \\
75-92 \\
48-74\end{array}$ & $\begin{array}{l}0.892 \\
0.910 \\
0.888\end{array}$ & $\begin{array}{l}0.68 \\
0.93 \\
0.75\end{array}$ & $\begin{array}{l}2007 \\
2008\end{array}$ & $\begin{array}{l}5 \\
5\end{array}$ & $\begin{array}{l}32-37 \\
34-40\end{array}$ & $\begin{array}{l}0.679 \\
0.783\end{array}$ & $\begin{array}{l}0.44 \\
0.50\end{array}$ \\
\hline $\begin{array}{l}\text { Wetlands } \\
n=9\end{array}$ & $\begin{array}{l}\text { Willow, } \\
\text { Fen }\end{array}$ & $\begin{array}{l}2007 \\
\text { May-Jul } 2008 \\
\text { Aug-Oct } 2008\end{array}$ & $\begin{array}{l}1,2 \\
1,2 \\
1,2\end{array}$ & $\begin{array}{l}81-82 \\
35-78 \\
44-66\end{array}$ & $\begin{array}{l}0.834 \\
0.906 \\
0.858\end{array}$ & $\begin{array}{l}1.71 \\
1.91 \\
1.58\end{array}$ & $\begin{array}{l}2007 \\
2008\end{array}$ & $\begin{array}{l}5 \\
5\end{array}$ & $\begin{array}{l}28-32 \\
32-35\end{array}$ & $\begin{array}{l}0.703 \\
0.788\end{array}$ & $\begin{array}{l}0.77 \\
0.91\end{array}$ \\
\hline
\end{tabular}

* The response functions used:

$1: \mathrm{GP}=Q \times \mathrm{PAR} /(k+\mathrm{PAR}) \times \exp \left(-0.5 \times\left(\left(T_{2 \mathrm{~cm}}-T_{\mathrm{opt}}\right) / T_{\mathrm{tol}}\right)^{2}\right) \times(a+\mathrm{LAI}) ; 2: \mathrm{GP}=Q \times \mathrm{PAR} /(k+\mathrm{PAR}) \times \exp \left(-0.5 \times\left(\left(T_{\mathrm{mean}}-T_{\mathrm{opt}}\right) / T_{\mathrm{tol}}\right)^{2}\right) \times(a+\mathrm{LAI}) ;$

$3: \mathrm{GP}=Q \times \mathrm{PAR} /(k+\mathrm{PAR}) \times T_{2} \mathrm{~cm} \times(a+\mathrm{LAI}) ; 4: \mathrm{GP}=Q \times \mathrm{PAR} /(k+\mathrm{PAR}) \times \exp \left(-0.5 \times\left(\left(T_{\mathrm{mean}}-T_{\mathrm{opt}}\right) / T_{\mathrm{tol}}\right)^{2}\right) \times M ; 5: \mathrm{ER}=R_{10} \times \exp \left(E_{0} \times(1 / 56-\right.$

$\left.\left.1 /\left(T_{\text {mean }}+46\right)\right)\right)$.

$Q=$ Maximum GP; $k=$ PAR level at which GP reaches half of $Q ; T_{2} \mathrm{~cm}=$ Soil temperature at $2 \mathrm{~cm} ; T_{\text {mean }}=$ Average of air temperature and $T_{2} \mathrm{~cm} ; T_{\mathrm{opt}}=$ Temperature optimum of GP; $T_{\text {tol }}=$ Temperature tolerance of GP; $a=$ Correction term for LAI; $M=$ The volumetric soil moisture; $R_{10}=\mathrm{ER}$ at $10{ }^{\circ} \mathrm{C} ; E_{0}=\mathrm{Activation}$ energy of ER.

model followed Repo et al. (2007). Surface water samples were collected during daytime (08:00 a.m.-19:00 p.m.). Linearly interpolated daily $\mathrm{CO}_{2}$ concentrations and hourly wind speed (measured at $2 \mathrm{~m}$, normalized to $10 \mathrm{~m}$ using a logarithmic wind profile) were used to calculate hourly flux rates. Ebullitive $\mathrm{CO}_{2}$ flux was monitored with permanently installed submerged funnel gas collectors (Repo et al., 2007). Each lake had 6-7 replicate gas collectors $(\varnothing 0.35 \mathrm{~m})$. Gas samples were stored and analyzed as described above.

\subsection{Carbon dioxide exchange at landscape scale}

\subsubsection{Eddy covariance setup}

Landscape-scale NEE was measured in May-October 2008 (139-280 days) at a frequency of $10 \mathrm{~Hz}$ using the micrometeorological EC method (Aubinet et al., 2000; Baldocchi, 2003). The system was set up with an R3 ultrasonic anemometer (Gill Instruments, UK) and an LI-7500 openpath $\mathrm{CO}_{2} / \mathrm{H}_{2} \mathrm{O}$ IRGA (LI-COR) mounted at $3.95 \mathrm{~m}$ height. The power was supplied by a fuel generator placed $40 \mathrm{~m}$ eastsoutheast $\left(110^{\circ}\right)$ of the mast.

\subsubsection{Data processing}

The raw data were processed using the Alteddy software (version 3.5, University of Wageningen, the Netherlands, http://www.climatexchange.nl/projects/alteddy/), which is based on EUROFLUX methodology (Aubinet et al., 2000). The means and variances of turbulent $\mathrm{CO}_{2}$ fluxes (=NEE) were calculated in half-hour time steps.
The open-path gas analyzer bears the disadvantage of self heating of the instrument surface which may result in overestimation of the $\mathrm{CO}_{2}$ uptake especially under cold conditions (e.g., Goulden et al., 2006; Ono et al., 2008). To account for this effect we applied the correction proposed by Burba et al. (2008). The quality of the data was assessed using quality flags according to Foken et al. (2004), and only data with quality flags between 1 and 6 were included in the final data set. Furthermore, data were rejected when measured during rain and fog events, when the wind was from the direction of the generator $\left(90\right.$ to $\left.130^{\circ}\right)$ and when friction velocity $\left(u^{*}\right)$ was $<0.1 \mathrm{~m} \mathrm{~s}^{-1}$. Out of the 6835 measured half-hourly NEE fluxes, $50 \%$ passed these criteria.

Subsequent gaps in the time series were filled using an online tool (http://www.bgc-jena.mpg.de/bgc-mdi/html/ eddyproc/) based on the algorithms by Falge et al. (2001) and Reichstein et al. (2005). A nighttime gap from 25 August to 6 October 2008 (238-280 days) was filled using a regression function based on soil temperature (Lloyd and Taylor, 1994; see below). During this period, $70 \%$ of the nighttime values had to be discarded due to rain events, dew formation or low turbulence conditions, which made the use of the online tool unfeasible.

\subsubsection{Nighttime fluxes and flux partitioning}

Measured NEE was partitioned into its components, GP and ER, by modeling ER based on its temperature response. For this purpose, we used the nighttime NEE (PAR $<50 \mu \mathrm{mol} \mathrm{m}^{-2} \mathrm{~s}^{-1}$ ) that is equal to ER. Only flux data with a quality flag 1-3 were used. The regression was 
performed on nightly average fluxes and soil temperatures by fitting data into an Arrhenius type function (Lloyd and Taylor, 1994):

$R_{\mathrm{ECO}}=R_{10} \cdot \exp \left(308.6 \cdot(1 / 56)-\left(1 /\left(T_{\mathrm{S}}+46\right)\right)\right)$,

where $R_{10}$ is the ER at $10^{\circ} \mathrm{C}$ and $T_{\mathrm{S}}$ is the soil temperature at $5 \mathrm{~cm}$ in ${ }^{\circ} \mathrm{C}$. GP was calculated as a difference between NEE and ER. The temperature response of ER is shown in Supplement Fig. S2.

\subsubsection{Footprint analysis}

The flux measured by the EC technique originates from a large number of ground level points located on various land cover types in the EC source area, the so-called footprint. The footprint area varies according to meteorological conditions. In order to upscale the results of the plot-scale measurements to the landscape scale we needed to know the contribution of each grid cell of the QuickBird image to the EC flux. The contribution of each $2.4 \mathrm{~m} \times 2.4 \mathrm{~m}$ grid cell within a $2.5 \mathrm{~km}$ radius around the $\mathrm{EC}$ mast was calculated by spatial integration of a source weight function for hourly observation intervals. The footprint analysis was performed in MATLAB R2009a using the footprint model originally developed in 2D by Gash (1986) and Schuepp et al. (1990) and expanded for use in 3-D by Soegaard et al. (2003). By superimposing these grid source weights upon the land cover classification and LAI map (see Sect. 2.5.), the contribution of each land cover type to the recorded flux and the mean LAI of the footprint could be estimated for upscaling purposes.

\subsection{Upscaling of the fluxes using remote sensing data}

\subsubsection{Land cover classification}

The land cover classification, used as one method for scaling up the $\mathrm{CO}_{2}$ balance, was based on a QuickBird satellite image covering $98.6 \mathrm{~km}^{2}$ around the flux measurement site, acquired on 6 July 2007 (QuickBird ${ }^{\circledR}$ 2007, DigitalGlobe; Distributed by Eurimage/Pöyry) (Fig. 1a). Four channels were used in the classification procedure (blue, green, red and infrared (NIR); pixel size $2.4 \mathrm{~m}$ ). Classifications were produced using a multiple level segmentation in the Definiens Professional 5.0 software. In the segmentation process, the neighboring pixels of the image are grouped together to form uniform regions using information on the spectral properties of the pixels. Vegetation descriptions made at 150 transect points and additional field notes and photographs were used as ground-truthing data. The classification was tested using vegetation descriptions from 130 randomly selected field points. The classification is described in more detail by Hugelius et al. (2011).

From the total of 13 land cover types distinguished from the satellite image, 8 were studied with plot-scale techniques
(Fig. 1a; Table 2). Five land cover types corresponded directly to microsites studied at plot scale, while some incorporated more than one microsite type. The relative contribution of different microsites within these land cover types was estimated from photographs taken at transect points around the EC mast. The chamber fluxes of different land cover types were weighed by their relative area contributions in order to obtain $\mathrm{CO}_{2}$ balance over the study area. For rivers, we used the $\mathrm{CO}_{2}$ emission of $33 \mathrm{~g} \mathrm{C} \mathrm{m}^{-2}$ during the open water period (100 days), measured in the same region by Heikkinen et al. (2004). A zero $\mathrm{CO}_{2}$ balance was assumed for forest stands, sand and impacted tundra.

\subsubsection{Leaf area index mapping}

An alternative upscaling data set, a LAI map, was developed based on the same QuickBird satellite image as was used for the land cover classification. The LAI map was based on a regression model, where mean LAI values for growing period measured in the field (Fig. 1b) were predicted by NDVI (normalized difference vegetation index: $(\mathrm{NIR}-\mathrm{red}) /(\mathrm{NIR}+\mathrm{red}))$ and individual channel reflectance values. Mean values from a $5 \mathrm{~m}$ radius around the LAI measurement points were calculated from the QuickBird data in order to eliminate spatial inaccuracies caused by GPS device. Different transformations were tried for both LAI and satellite image variables, and the best model fit was obtained when the LAI values were square root transformed. NDVI was the best single explanatory variable to explain LAI (30\% of variation), and by adding channels 1 (blue) and 2 (green) the explanatory power was increased to $36 \%(n=284)$ :

$$
\begin{aligned}
\operatorname{sqrt}(\mathrm{LAI})= & 4.437 \cdot \mathrm{NDVI}+0.027 \cdot \text { Channel } 1-0.014 \\
& \text {. Channel } 2-2.784 .
\end{aligned}
$$

The residuals of the model were normally distributed. The rather large unexplained variation can be explained by the fact that the LAI measurements were made at single points and vegetation cover around them was not uniform enough to perfectly match the satellite data. When the model was applied to the whole QuickBird image, predicted negative LAI values were reclassified as 0 . Mean LAI of the terrestrial surfaces was calculated by subtracting the water bodies from the LAI of the whole region. Dependence between cumulative $\mathrm{CO}_{2}$ fluxes and LAI, observed for terrestrial microsites (see Sect. 3.3 and Fig. 6), was used to upscale the $\mathrm{CO}_{2}$ balance to landscape (EC footprint) and regional scales.

\subsection{Uncertainty estimates for the $\mathrm{CO}_{2}$ fluxes}

Uncertainty of the $\mathrm{CO}_{2}$ balance from area-integrated plotscale measurements was estimated by weighing the standard deviations (SDs) of hourly microsite fluxes with corresponding area contributions, and summing up these area-weighed SDs over time. This simple method probably gives a conservative estimate of the true uncertainty of the cumulative $\mathrm{CO}_{2}$ 
flux measured by chambers (see Bubier et al., 1999). For EC fluxes, the gap-filling procedure was considered as the main uncertainty factor due to the high percent of gap-filled values $(51 \%)$. Artificial gaps were added to the data set and subsequently modeled by the usual gap-filling procedure described above. These artificial gap-filled fluxes and the original fluxes showed a good agreement with a $R^{2}$ of 0.85 and RSME of $1.3 \mu \mathrm{mol} \mathrm{m}^{-2} \mathrm{~s}^{-1}$. The average daily difference between the artificial gap-filled and original measured fluxes was considered as the uncertainty of the EC flux.

\section{Results}

\subsection{Meteorology}

Air temperature and precipitation in 2007 and 2008 measured at the study site and the long-term averages from the nearby Vorkuta station are shown in Table 1. Air temperatures were above the long-term means in December and January. July was anomalously hot during both years, especially in 2007. The precipitation during the snow-free period 20072008 was mostly equal to the long-term mean. The length of the thermic growing season, defined as a period when the daily mean air temperature is permanently above $+5^{\circ} \mathrm{C}$, was 80 days in 2007 and 79 days in 2008. The permanent snow cover lasted from mid-October to mid-May-early June.

\subsection{LAI map}

The distribution of LAI values predicted by the regression model based on spectral satellite data is realistic when assessed in relation to the land cover classification (Fig. 1a,b). Overall mean LAI for the region was 0.98 ( $\max 5.36)$. The proportion of zero LAI values $(1.8 \%)$ matched very well to the coverage of water and non-vegetated soils in the land cover classification (1.6\%). There was a strong correlation between the LAI values measured at the chamber plots and those derived from the LAI map for the corresponding land cover types as a whole ( $p<0.05$; Fig. 2$)$. The only land cover types deviating from $1: 1$ line are fen and Betula nana tundra heath.

\subsection{Spatial variability in $\mathrm{CO}_{2}$ exchange}

Fig. 3 shows the raw chamber data that were used for building the regression functions to obtain hourly $\mathrm{CO}_{2}$ fluxes at the terrestrial microsites (Table 3 ). The regression functions were able to explain 86 and $74 \%$ of the observed overall variability in the measured GP and ER fluxes. Details of the GP and ER models are presented in the Supplement (Tables S1 and $\mathrm{S} 2$ ).

The spatial variability in soil conditions and vascular plant cover (Table 4) resulted in large differences in $\mathrm{CO}_{2}$ fluxes across the landscape (Figs. 4-5). The growing season ER of terrestrial microsites varied from 64 to $226 \mathrm{~g} \mathrm{C} \mathrm{m}^{-2}$, GP from

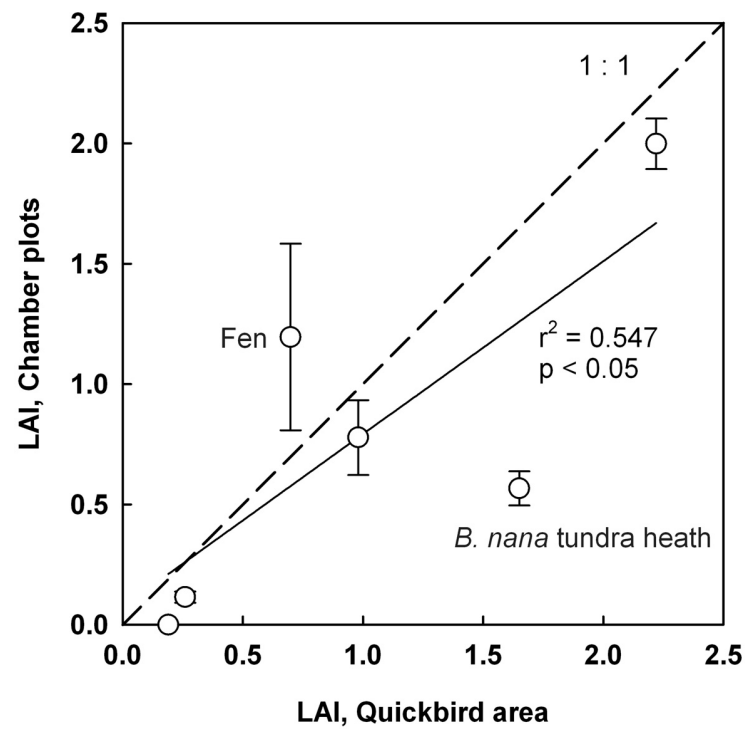

Fig. 2. Correlation of LAI values of different land cover types determined by two independent methods: field measurements at chamber microsites (mean $\pm \mathrm{SD} ; n=3-6$ ) and modeling based on satellite image data for the QuickBird area of $98.6 \mathrm{~km}^{2}$. The dashed line is a $1: 1$ line, and the solid line is a linear regression line fitted to the data. The two land cover classes deviating from $1: 1$ line have been named.

-31 to $-518 \mathrm{~g} \mathrm{C} \mathrm{m}^{-2}$ and NEE from -292 to $48 \mathrm{~g} \mathrm{C} \mathrm{m}^{-2}$. The annual $\mathrm{CO}_{2}$ balance ranged from -251 to $84 \mathrm{~g} \mathrm{C} \mathrm{m}^{-2}$. A general trend of increasing $\mathrm{C}$ uptake with increasing wetness was observed for the three main land cover types (upland tundra $<$ dry peatlands $<$ wetlands), and wetlands also had the highest ER (Fig. 4).

The mean LAI was an excellent predictor of the spatial variability in GP and NEE, and even in ER. The cumulative $\mathrm{CO}_{2}$ fluxes during the growing season were linearly dependent on LAI across all the terrestrial microsites studied (Fig. 6). Moreover, the predictive power of LAI was good also if the period under review was the whole EC measuring period (May-October), or even the full year (data not shown). These linear regression functions between LAI and $\mathrm{CO}_{2}$ flux, observed at plot scale, were used together with the LAI map to upscale the $\mathrm{CO}_{2}$ balance to landscape and regional scales (see Sect. 2.5.2.). The microsites with LAI $<0.3$ (dry shrub tundra heath, dry lichen tundra heath, bare peat, Eriophorum dominated fen) had the lowest GP and were net sources of $\mathrm{C}$ to the atmosphere on an annual basis. All the other microsites showed annual net uptake of C.

The thermokarst lakes studied were supersaturated with $\mathrm{CO}_{2}$ and, thus, atmospheric sources of this gas during the whole open water period (Fig. 7). The annual emissions of $\mathrm{CO}_{2}$ from the three lakes ranged from 13 to $82 \mathrm{~g} \mathrm{C} \mathrm{m}^{-2}$, averaging $43 \pm 35 \mathrm{~g} \mathrm{C} \mathrm{m}^{-2}$. Diffusion was the main pathway of $\mathrm{CO}_{2}$ release, the importance of ebullition being negligible. 
Table 4. Characteristics of the microsites measured with chamber technique: leaf area index (LAI), water table level (WT), soil moisture $\left(\theta_{v}\right)$ and maximum active layer depth $\left(\mathrm{AL}_{\max }\right)$. Data for $\mathrm{LAI}$ and $\theta_{v}$ are growing season means \pm standard error, whereas a range is shown for $\operatorname{AL}_{\max }(n=3)$.

\begin{tabular}{|c|c|c|c|c|c|c|c|}
\hline \multirow[b]{2}{*}{ Microsite } & \multirow{2}{*}{$\begin{array}{r}\text { LAI } \\
2008\end{array}$} & \multicolumn{2}{|c|}{ WT $(\mathrm{cm})$} & \multicolumn{2}{|c|}{$\theta_{v}\left(\mathrm{~m}^{3} \mathrm{~m}^{-3}\right)$} & \multicolumn{2}{|c|}{$\mathrm{AL}_{\max }(\mathrm{cm})$} \\
\hline & & 2007 & 2008 & 2007 & 2008 & 2007 & 2008 \\
\hline \multicolumn{8}{|l|}{ UPLAND TUNDRA } \\
\hline Shrub tundra heath, dry & $0.26 \pm 0.01$ & $32 \pm 1$ & $28 \pm 3$ & $0.17 \pm 0.00$ & $0.13 \pm 0.01$ & $\geq 106$ & $>120$ \\
\hline Shrub tundra heath, moist & $0.93 \pm 0.23$ & $32 \pm 3$ & $27 \pm 2$ & $0.22 \pm 0.02$ & $0.16 \pm 0.01$ & $>120$ & $>120$ \\
\hline Betula nana tundra heath & $0.53 \pm 0.06$ & $28 \pm 3$ & $32 \pm 2$ & $0.16 \pm 0.02$ & $0.12 \pm 0.02$ & $>120$ & $>120$ \\
\hline Dry lichen tundra heath & $0.11 \pm 0.02$ & $35 \pm 2$ & $39 \pm 2$ & $0.18 \pm 0.00$ & $0.14 \pm 0.01$ & $88 \pm 4$ & $94 \pm 4$ \\
\hline \multicolumn{8}{|l|}{ DRY PEATLANDS } \\
\hline Tundra bog, dry & $0.92 \pm 0.13$ & $34 \pm 2$ & $31 \pm 5$ & $0.16 \pm 0.01$ & $0.12 \pm 0.01$ & $49 \pm 3$ & $51 \pm 3$ \\
\hline Tundra bog, moist & $0.45 \pm 0.14$ & $14 \pm 1$ & $18 \pm 1$ & $0.43 \pm 0.02$ & $0.40 \pm 0.03$ & $76 \pm 2$ & $81 \pm 2$ \\
\hline Bare peat & 0.00 & $18 \pm 3$ & $23 \pm 4$ & $0.63 \pm 0.01$ & $0.60 \pm 0.01$ & $70 \pm 1$ & $62 \pm 1$ \\
\hline \multicolumn{8}{|l|}{ WETLANDS } \\
\hline Willow & $1.85 \pm 0.11$ & $0 \pm 1$ & $-1 \pm 1$ & n.d. & n.d. & $>120$ & $>120$ \\
\hline Fen, Carex dominated & $1.17 \pm 0.40$ & $8 \pm 1$ & $8 \pm 3$ & n.d. & n.d. & $>120$ & $>120$ \\
\hline Fen, Eriophorum dominated & $0.17 \pm 0.03$ & $-3 \pm 0$ & $1 \pm 2$ & n.d. & n.d. & $>120$ & $>120$ \\
\hline
\end{tabular}

Table 5. Carbon dioxide balance for the intensive measuring period in 2008 and full year (October 2007-October 2008). Estimates for the EC footprint area are shown for different measuring techniques (plot-scale measurements = chamber technique and lake measurements).

\begin{tabular}{|c|c|c|c|c|c|}
\hline \multirow[t]{2}{*}{ NEE, $\mathrm{g} \mathrm{C} \mathrm{m}^{-2}$} & \multicolumn{4}{|c|}{ EC measuring period } & Full year \\
\hline & $\begin{array}{r}\text { Early season } \\
\text { days } \\
139-167\end{array}$ & $\begin{array}{r}\text { Growing season } \\
\text { days } \\
168-246\end{array}$ & $\begin{array}{r}\text { Late season } \\
\text { days } \\
247-279\end{array}$ & $\begin{array}{r}\text { Total } \\
\text { days } \\
139-279\end{array}$ & $\begin{array}{r}\text { (days } 279 / 2007 \\
-279 / 2008 \text { ) }\end{array}$ \\
\hline $\begin{array}{l}\text { EC footprint, } \mathbf{0 . 2}-\mathbf{0 . 5} \mathbf{~ k m}^{2} \mathbf{k m}^{2} \\
\text { Plot-scale measurements } \\
\text { upscaled with land } \\
\text { cover classification }\end{array}$ & $7 \pm 3$ & $-81 \pm 37$ & $4 \pm 6$ & $-70 \pm 46$ & $-32 \pm 57$ \\
\hline $\begin{array}{l}\text { Plot-scale measurements } \\
\text { upscaled with LAI map }\end{array}$ & n.d. & $-105 \pm 27$ & n.d. & $-93 \pm 23$ & $-57 \pm 20$ \\
\hline EC measurements & $20 \pm 4$ & $-79 \pm 35$ & $32 \pm 10$ & $-28 \pm 50$ & n.d. \\
\hline $\begin{array}{l}\text { QuickBird area, } 98.6 \mathbf{k m}^{2} \\
\text { Plot-scale measurements } \\
\text { upscaled with land } \\
\text { cover classification }\end{array}$ & $8 \pm 3$ & $-94 \pm 37$ & $3 \pm 5$ & $-82 \pm 46$ & $-41 \pm 57$ \\
\hline $\begin{array}{l}\text { Plot-scale measurements } \\
\text { upscaled with LAI map }\end{array}$ & n.d. & $-127 \pm 30$ & n.d. & $-117 \pm 26$ & $-79 \pm 22$ \\
\hline
\end{tabular}

n.d. $=$ not determined.

The maximum $\mathrm{CO}_{2}$ release from lakes, $\sim 1.0 \mathrm{~g} \mathrm{C} \mathrm{m}^{-2} \mathrm{~d}^{-1}$, was moderate compared to the ER in terrestrial microsites.

\subsection{Temporal variability $\mathrm{CO}_{2}$ exchange}

\subsubsection{Seasonal variations}

Plot-scale fluxes showed an initiation of the summer uptake period on day $170-178$, while the first day with daily net $\mathrm{C}$ uptake observed by EC was day 174 (Fig. 4). Both nighttime respiration and daytime net uptake measured by EC reached the maximum values during the second half of July, being $4 \mu \mathrm{mol} \mathrm{m} \mathrm{m}^{-2} \mathrm{~s}^{-1}$ and $-8 \mu \mathrm{mol} \mathrm{m} \mathrm{m}^{-2} \mathrm{~s}^{-1}$, respectively. In autumn, the EC measurements indicated a shift to a daily source by day 240 , while area integrated plot-scale measurements indicated this only on day 258 (Fig. 3). The seasonal amplitude of NEE was higher for EC fluxes than for the area integrated plot-scale measurements, i.e., EC showed higher net 

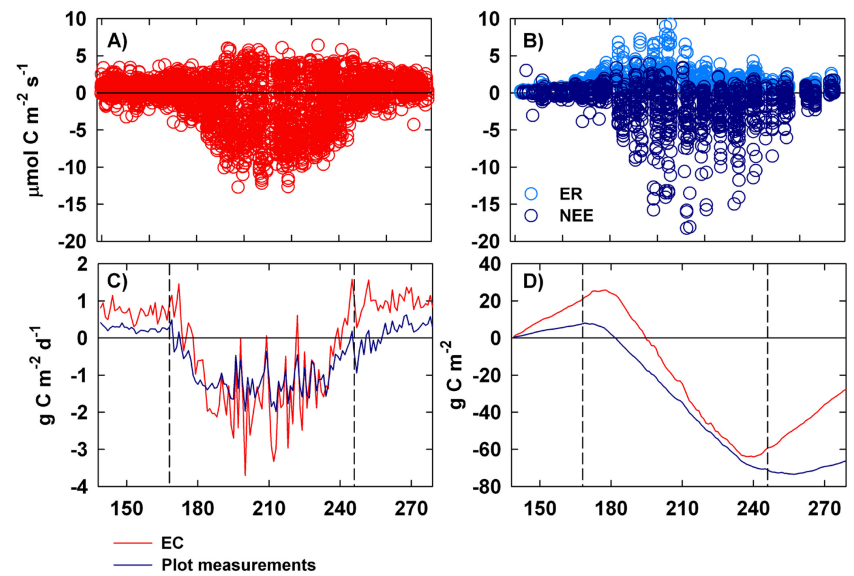

Fig. 3. Carbon dioxide fluxes of the EC footprint area in 2008 based on EC (red) and plot-scale measurements (chambers, snow gradient and lake measurements; blue). (A) Non-gap-filled half-hourly NEE from EC; (B) raw chamber data: NEE under ambient and reduced light and ER; (C) daily NEE fluxes by the two methods; (D) cumulative NEE by the two methods. Positive values indicate $\mathrm{C}$ loss from the ecosystem, negative values $\mathrm{C}$ uptake. The daily and cumulative plot-scale fluxes have been integrated over time with regression functions and area-weighed for the EC footprint using the land cover classification. The dashed lines indicate the start and end of the growing season.

uptake rates during mid-summer and higher net $\mathrm{CO}_{2}$ release during spring and autumn.

Based on the plot-scale measurements, the non-growing season ER comprised $25-45 \%$ of the annual ER. The measured values of wintertime respiration were 0 $0.24 \mu \mathrm{mol} \mathrm{m}^{-2} \mathrm{~s}^{-1}$ in January and $0-0.22 \mu \mathrm{mol} \mathrm{m}^{-2} \mathrm{~s}^{-1}$ in March. The area-weighed ER for the EC footprint based on modeled ER of different land cover types was within the range of the measured respiration rates: 0.13 and $0.11 \mu \mathrm{mol} \mathrm{m}^{-2} \mathrm{~s}^{-1}$ for January and March, respectively. We observed a clear peak in ER at topsoil $(2 \mathrm{~cm})$ temperatures $\sim 0{ }^{\circ} \mathrm{C}$ in upland tundra and dry peatlands, but not in wetlands (Supplement Fig. S1). The peak was more pronounced in the spring than in the fall.

\subsubsection{Interannual variations}

Interannual comparison is limited to July and August, the only months with intensive chamber measurements during both study years (Fig. 8$)$. Upland tundra $(n=12)$ had $25 \%$ higher ER in July-August 2007 than in 2008 (Wilcoxon signed-ranks test; $p<0.05$ ). $75 \%$ of the cumulative difference in ER occurred in July, which had higher air and topsoil temperatures in 2007 than in 2008. As a result of the higher respiration, the net $\mathrm{C}$ sink on upland tundra was lower by $50 \%$ in 2007, while the GP was similar during both years. No interannual differences were observed in the peak-season GP, NEE or ER on wetlands and dry peatlands. The $\mathrm{CO}_{2}$

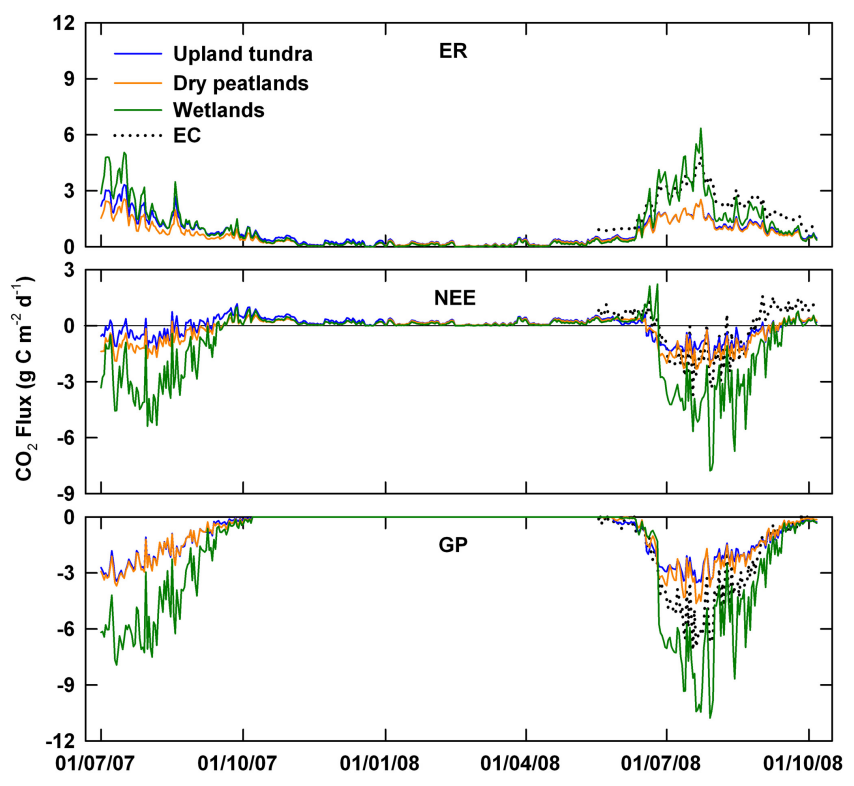

Fig. 4. Seasonal dynamics of $\mathrm{CO}_{2}$ fluxes of the three main landscape types (upland tundra, dry peatlands and wetlands) based on chamber measurements and integrated landscape-scale $\mathrm{CO}_{2}$ flux from eddy covariance. Data are daily mean values.

emissions from thermokarst lakes were of similar magnitude in growing seasons 2007 and $2008\left(20 \pm 18 \mathrm{~g} \mathrm{C} \mathrm{m}^{-2}\right.$ and $29 \pm 22 \mathrm{~g} \mathrm{C} \mathrm{m}^{-2}$, respectively).

\subsection{Comparison of $\mathrm{CO}_{2}$ balances by the two measuring techniques in landscape scale}

The EC and area integrated plot-scale measurements resulted in similar $\mathrm{CO}_{2}$ sink strength for the $\mathrm{EC}$ footprint during growing season $2008\left(-81 \pm 37 \mathrm{~g} \mathrm{C} \mathrm{m}^{-2}\right.$ vs. $-105 \pm 27$ to $-79 \pm 35 \mathrm{~g} \mathrm{C} \mathrm{m}^{-2}$, respectively; Table 5). Outside the growing season EC showed a higher source than the plot-scale measurements (upscaled with land cover classification), the mean difference being $0.44 \mathrm{~g} \mathrm{C} \mathrm{m}^{-2} \mathrm{~d}^{-1}$ in the early season and $0.82 \mathrm{~g} \mathrm{C} \mathrm{m}^{-2} \mathrm{~d}^{-1}$ in the late season. Still, the $\mathrm{CO}_{2}$ balances based on the two methods were within the error range of each other for the whole EC measuring period of 141 days. Upscaling with the LAI map resulted in a somewhat stronger sink than upscaling with the land cover classification, but the difference was not significant.

The partitioning approach used for the EC fluxes (Fig. 4) allows the comparison of the two $\mathrm{CO}_{2}$ flux components, ER and GP, between the two methods. Although the EC and area-integrated chambers resulted in similar cumulative NEE for the growing season, the plot-scale measurements showed lower fluxes to both directions. Cumulative ER and GP for the growing season from EC were 226 and $-305 \mathrm{~g} \mathrm{C} \mathrm{m}^{-2}$ $(-\mathrm{ER} / \mathrm{GP}=0.74)$ and from plot-scale measurements 111 to 130 and -233 to $-188 \mathrm{~g} \mathrm{C} \mathrm{m}^{-2}(-\mathrm{ER} / \mathrm{GP}=0.56-0.59)$. 


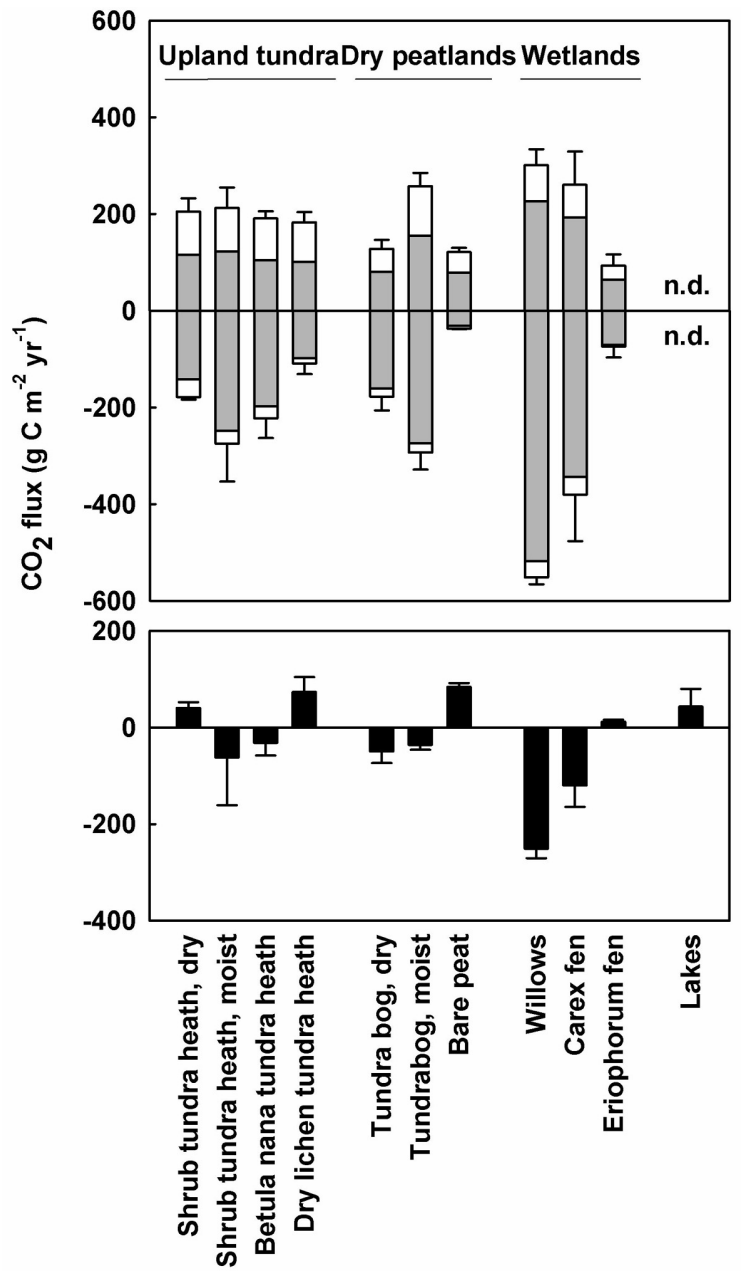

Fig. 5. The annual $\mathrm{CO}_{2}$ balance (6 October 2007-5 October 2008) at different microsites: ER and GP (top), NEE (bottom) (mean $\pm \mathrm{SD} ; n=3$ ). The ER and GP are divided into growing season and non-growing season fluxes. Positive values mean $\mathrm{C}$ loss from the ecosystem and negative values $\mathrm{C}$ uptake.

\subsection{Seasonal and annual $\mathrm{CO}_{2}$ balance for the study region}

After verifying the plot-scale fluxes by comparing them with the EC results in the landscape scale, we scaled them up to the whole QuickBird area of $98.6 \mathrm{~km}^{2}$. The regional $\mathrm{CO}_{2}$ balance during the growing season 2008 was $-127 \pm 30$ to $-94 \pm 37 \mathrm{~g} \mathrm{C} \mathrm{m}^{-2}$ based on the two independent upscaling approaches. The annual $\mathrm{CO}_{2}$ balance (NEE) for the study region was $-79 \pm 22$ to $-41 \pm 57 \mathrm{~g} \mathrm{C} \mathrm{m}^{-2}$, consisting of ER of $197 \pm 35$ to $212 \pm 50 \mathrm{~g} \mathrm{C} \mathrm{m}^{-2}$ and GP of $-294 \pm 58$ to $-238 \pm 39 \mathrm{~g} \mathrm{C} \mathrm{m}^{-2} .33-39 \%$ of the annual ER and $8-10 \%$ of the annual GP occurred outside the growing season. The study region as a whole was a $16-21 \%$ stronger $\mathrm{CO}_{2}$ sink than the EC footprint area, which corresponds to a difference in LAI between the two scales ( 0.98 vs. 0.83 for the whole study region and EC footprint, respectively). The EC foot-

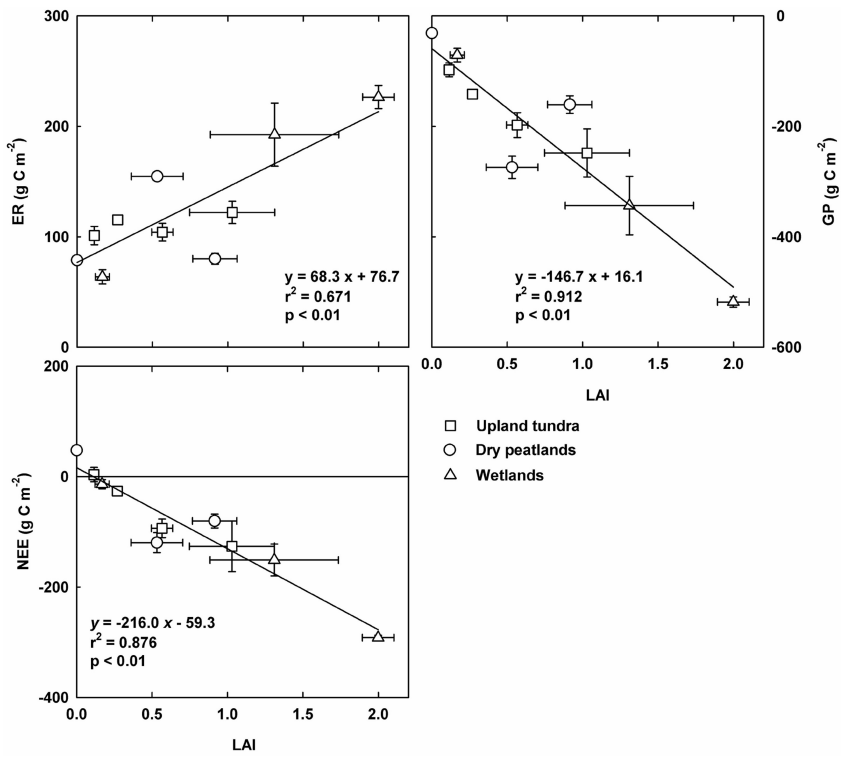

Fig. 6. Dependence between mean LAI and cumulative C fluxes for the growing season 2008 (days 168-246). Each data point represents one of the ten chamber microsites (mean $\pm \mathrm{SD} ; n=3$ ).

print had, e.g., more tundra bog and lakes and less willow than the whole region (Supplement Fig. S3).

\section{Discussion}

\subsection{Plot-scale $\mathrm{CO}_{2}$ fluxes}

Despite the heterogeneity of the studied landscape, a clear trend was found to explain the spatial variability in $\mathrm{CO}_{2} \mathrm{ex}-$ change. Vascular LAI explained $\sim 90 \%$ of the variability in the growing season GP and NEE across the chamber microsites, and even for ER its explanatory power was $67 \%$. Given that the response functions for interpolating the $\mathrm{CO}_{2}$ fluxes were determined independently for each microsite, this was a true dependence, not a modeling artifact. Also, in earlier studies on tundra and peatland ecosystems LAI has explained well the spatial variability in GP (Lund et al., 2010) or both GP and ER (Soegaard et al., 2000; McFadden et al., 2003; Humphreys et al., 2006). Positive correlation between ER and LAI may be explained by dominance of autotrophic respiration over microbial decomposition of soil organic matter (heterotrophic respiration), or a tight link between these two respiration components through, e.g., rhizomicrobial respiration (Hutsch et al., 2002). Since non-destructive LAI measurements with a plant canopy analyzer are fast and easy and can be related to remote sensing data, the strong relationship between LAI and $\mathrm{CO}_{2}$ fluxes is very promising from the upscaling point of view. Still, multiyear studies are needed to verify how strongly the shape and slope of the $\mathrm{CO}_{2}$ flux-LAI dependence are affected by interannual variability in weather conditions. 
Table 6. Summary of cumulative NEE and GP in different tundra ecosystems based on chamber and eddy covariance (EC) measurements and modeling. From chambers studies only those with area-integrated estimates were included. Ranges indicate the spatio-temporal variability of $\mathrm{CO}_{2}$ fluxes.

\begin{tabular}{|c|c|c|c|c|c|c|}
\hline \multirow[t]{2}{*}{ Location } & \multirow[t]{2}{*}{$\begin{array}{l}\text { Tundra type } \\
\text { (max. LAI) }\end{array}$} & \multirow[t]{2}{*}{$\begin{array}{l}\text { Period } \\
\text { (days) }\end{array}$} & \multicolumn{2}{|c|}{$\begin{array}{l}\text { Cumulative } \mathrm{CO}_{2} \text { flux } \\
\qquad\left(\mathrm{g} \mathrm{C} \mathrm{m}^{-2}\right)\end{array}$} & \multirow[t]{2}{*}{ Method } & \multirow[t]{2}{*}{ Reference } \\
\hline & & & NEE & GP & & \\
\hline $\begin{array}{l}\text { Ny-Ålesund, Svalbard } \\
\left(79^{\circ} \mathrm{N}, 12^{\circ} \mathrm{E}\right)\end{array}$ & High arctic heath & $\begin{array}{l}\text { Jun-Sep } \\
\text { (70-89 days) }\end{array}$ & -9 to +5 & & $\begin{array}{l}\text { EC with } \\
\text { modeling }\end{array}$ & (Lloyd, 2001) \\
\hline $\begin{array}{l}\text { Zackenberg, } \\
\text { Greenland } \\
\left(74^{\circ} \mathrm{N}, 21^{\circ} \mathrm{W}\right)\end{array}$ & $\begin{array}{l}\text { High arctic heath, } \\
\text { willows, fen } \\
(\mathrm{LAI}=0.2-1.1) \\
\text { Jun-Aug } \\
(\mathrm{LAI}=0.2-0.3)\end{array}$ & $\begin{array}{l}\text { Jun-Aug } \\
\text { (92 days) } \\
\text { Annual } \\
-23 \text { to }-1 \\
\text { (80 days) } \\
\text { Jun-Aug } \\
\text { ( } 73 \text { days) }\end{array}$ & $\begin{array}{r}-10(-33 \text { to }-1) \\
-2(-19 \text { to }+\mathbf{5})\end{array}$ & -95 to -54 & $\begin{array}{l}\text { EC with } \\
\text { modeling } \\
\text { EC } \\
\text { EC }\end{array}$ & $\begin{array}{l}\text { (Soegaard et al., } \\
2000 \text { ) } \\
\text { (Groendahl et al., } \\
2007 \text { ) } \\
\text { (Lund et al., } \\
2012 \text { ) }\end{array}$ \\
\hline $\begin{array}{l}\text { Lena Delta, Russia } \\
\left(72^{\circ} \mathrm{N}, 127^{\circ} \mathrm{E}\right)\end{array}$ & Polygonal tundra & $\begin{array}{l}\text { Jun-Aug } \\
\text { (81 days) } \\
\text { Annual }\end{array}$ & $\begin{array}{l}-32 \\
-19\end{array}$ & -118 & $\mathrm{EC}$ & $\begin{array}{l}\text { (Kutzbach et al., } \\
\text { 2007b) }\end{array}$ \\
\hline $\begin{array}{l}\text { Barrow, Alaska } \\
\left(70-71^{\circ} \mathrm{N}, 157^{\circ} \mathrm{W}\right)\end{array}$ & $\begin{array}{l}\text { Sedge tundra } \\
\text { Sedge tundra, } \\
\text { tussock tundra }\end{array}$ & $\begin{array}{l}\text { May-Sep } \\
\text { (147 days) } \\
\text { Jun-Aug } \\
\text { (92 days) }\end{array}$ & $\begin{array}{r}-162 \text { to }-105 \\
-70 \text { to }+61\end{array}$ & -215 to -147 & $\begin{array}{l}\mathrm{EC} \\
\mathrm{EC}\end{array}$ & $\begin{array}{l}\text { (Harazono et al., } \\
2003 \text { ) } \\
\text { (Kwon et al., } \\
\text { 2006) }\end{array}$ \\
\hline $\begin{array}{l}\text { Indigirka, Russia } \\
\left(71^{\circ} \mathrm{N}, 147^{\circ} \mathrm{E}\right)\end{array}$ & Lowland tundra & $\begin{array}{l}\text { Annual } \\
\text { Growing } \\
\text { season } \\
\text { (60-81 days) }\end{array}$ & $\begin{array}{r}-92 \\
-95 \text { to }-69\end{array}$ & $\begin{array}{r}-\mathbf{2 3 2} \\
-211 \text { to }-158\end{array}$ & $\begin{array}{l}\text { EC, } \\
\text { chambers } \\
\text { EC }\end{array}$ & $\begin{array}{l}\text { (van der Molen et al., } \\
\text { 2007) } \\
\text { (Parmentier et } \\
\text { al., 2011) }\end{array}$ \\
\hline $\begin{array}{l}\text { Happy Valley, } \\
\text { Alaska } \\
\left(69^{\circ} \mathrm{N}, 149^{\circ} \mathrm{W}\right)\end{array}$ & $\begin{array}{l}\text { Sedge tundra, } \\
\text { tussock tundra }\end{array}$ & $\begin{array}{l}\text { Jun-Aug } \\
\text { (81 days) } \\
\text { Jun-Aug } \\
\text { (92 days) }\end{array}$ & $\begin{array}{r}-40 \\
-77 \text { to }-55\end{array}$ & -234 to -142 & $\begin{array}{l}\text { EC } \\
\text { EC }\end{array}$ & $\begin{array}{l}\text { (Vourlitis and } \\
\text { Oechel, 1997) } \\
\text { (Vourlitis et al., } \\
\text { 2000) }\end{array}$ \\
\hline $\begin{array}{l}\text { Cherskii, Russia } \\
\left(69^{\circ} \mathrm{N}, 161^{\circ} \mathrm{E}\right)\end{array}$ & $\begin{array}{l}\text { Tussock tundra } \\
(\mathrm{LAI}=1.4)\end{array}$ & $\begin{array}{l}\text { Jul-Oct } \\
\text { (100 days) } \\
\text { Annual }\end{array}$ & $\begin{array}{r}-50 \text { to }+15 \\
-\mathbf{3 8}\end{array}$ & & $\begin{array}{l}\text { EC } \\
\text { EC }\end{array}$ & $\begin{array}{l}\text { (Merbold et al., } \\
\text { 2009) } \\
\text { (Corradi et al., } \\
2005 \text { ) }\end{array}$ \\
\hline $\begin{array}{l}\text { Stordalen, Sweden } \\
\left(68^{\circ} \mathrm{N}, 19^{\circ} \mathrm{E}\right)\end{array}$ & $\begin{array}{l}\text { Subarctic palsa } \\
\text { mire }\end{array}$ & Annual & $-\mathbf{3}$ & & Chambers & $\begin{array}{l}\text { (Bäckstrand et al., } \\
\text { 2010) }\end{array}$ \\
\hline $\begin{array}{l}\text { Abisco, Sweden } \\
\left(68^{\circ} \mathrm{N}, 19^{\circ} \mathrm{E}\right)\end{array}$ & $\begin{array}{l}\text { Fell field, } \\
\text { heath, } \\
\text { fen, } \\
\text { shrub tundra }\end{array}$ & $\begin{array}{l}\text { Jul-Aug } \\
\text { (40 days) }\end{array}$ & $\begin{array}{r}-60 \text { to }-66 \\
(-158 \text { to }-10) \\
-38 \text { to }-33\end{array}$ & & $\begin{array}{l}\text { Chambers } \\
\text { EC }\end{array}$ & (Fox et al., 2008) \\
\hline $\begin{array}{l}\text { Lek Vorkuta, Russia } \\
\left(67^{\circ} \mathrm{N}, 63^{\circ} \mathrm{E}\right)\end{array}$ & $\begin{array}{l}\text { Various tundra } \\
\text { types (100 days) }\end{array}$ & $\begin{array}{l}\text { Jun-Aug } \\
(-124 \text { to }+123)\end{array}$ & $\begin{array}{r}-35 \\
(-325 \text { to }-78)\end{array}$ & n.a. & Chambers & $\begin{array}{l}\text { (Heikkinen et al., } \\
\text { 2004) }\end{array}$ \\
\hline $\begin{array}{l}\text { Chukotskiy, Russia } \\
\left(66^{\circ} \mathrm{N}, 171^{\circ} \mathrm{E}\right)\end{array}$ & Typical tundra & $\begin{array}{l}\text { Jul-Oct } \\
\text { ( } 85 \text { days) }\end{array}$ & -10 & -96 & $\begin{array}{l}\text { EC, } \\
\text { chambers }\end{array}$ & $\begin{array}{l}\text { (Zamolodchikov } \\
\text { et al., 2003) }\end{array}$ \\
\hline $\begin{array}{l}\text { Daring Lake, Canada } \\
\left(65^{\circ} \mathrm{N}, 112^{\circ} \mathrm{W}\right)\end{array}$ & $\begin{array}{l}\text { Low arctic tundra } \\
(\mathrm{LAI}=0.6-0.9)\end{array}$ & $\begin{array}{l}\text { May-Sep } \\
\text { (109 days) }\end{array}$ & -111 to -32 & -209 to -132 & $\mathrm{EC}$ & $\begin{array}{l}\text { (Lafleur and Humphreys, } \\
\text { 2008; Humphreys } \\
\text { and Lafleur, 2011) }\end{array}$ \\
\hline $\begin{array}{l}\text { Russian tundra } \\
\left(64-76^{\circ} \mathrm{N}, 30-172^{\circ} \mathrm{W}\right)\end{array}$ & $\begin{array}{l}\text { East-European } \\
\text { tundra } \\
\text { Whole Russian } \\
\text { tundra }\end{array}$ & $\begin{array}{l}\text { Annual } \\
\text { Annual }\end{array}$ & $\begin{array}{l}-4 \\
-5\end{array}$ & $\begin{array}{l}-334 \\
-207\end{array}$ & $\begin{array}{l}\text { Chambers } \\
\text { with } \\
\text { modeling }\end{array}$ & $\begin{array}{l}\text { (Zamolodchikov, } \\
\text { and Karelin } \\
\text { 2001) }\end{array}$ \\
\hline
\end{tabular}



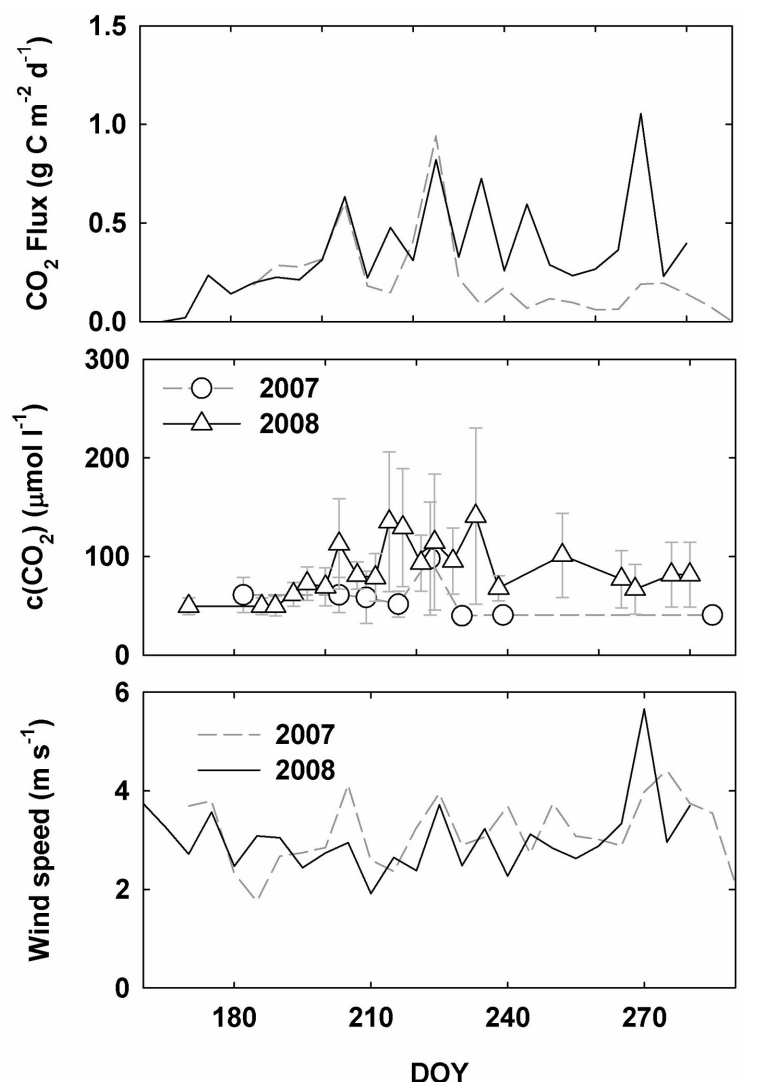

Fig. 7. $\mathrm{CO}_{2}$ flux in thermokarst lakes during the open water period (top), $\mathrm{CO}_{2}$ concentration in the surface water (middle) and local wind speed at $2 \mathrm{~m}$ (bottom) $(n=3)$. Flux and wind speed data are 5-day averages, whereas $\mathrm{CO}_{2}$ concentrations in the surface water are shown for each sampling occasion (mean $\pm \mathrm{SD}$ ).

We did not observe significant differences in GP between the study years at any of the land cover types. However, the peak summer ER was higher and net $\mathrm{CO}_{2}$ sink smaller on upland tundra in 2007, which was the warmer of the two years. There was no similar increase in ER at the peatland sites, most probably due to wetter soil conditions that were limiting soil respiration over temperature. In the same region Heikkinen et al. (2004) measured higher ER from non-waterlogged soils during the warmer and drier of the two study years, and Zamolodchikov et al. (2000) observed a switch in net $\mathrm{C}$ flux from sink to source in shrub tundra communities when canopy temperature rose above $+14^{\circ} \mathrm{C}$. Also, multiannual EC flux studies in other tundra regions have indicated good adaptation of certain vegetation communities to the present temperatures, seen as reduced net $\mathrm{C}$ sink during warm summers (Parmentier et al., 2011; Lund et al., 2012).

The wintertime ER data obtained by plot-scale measurements are within the range reported earlier for similar ecosystems. Our mean $\mathrm{CO}_{2}$ efflux in January-March was similar to winter time respiration reported for northern peatlands and tundra (e.g., Oechel et al., 1997; Elberling, 2007;

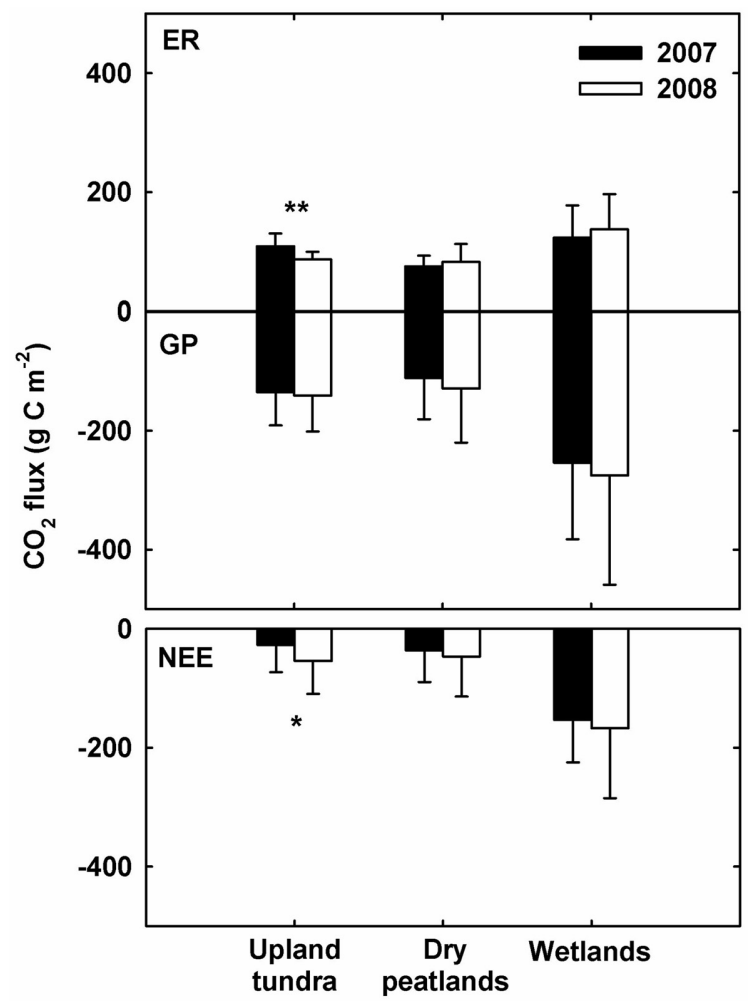

Fig. 8. Cumulative $\mathrm{CO}_{2}$ fluxes during summer period (July-August) in the three main land cover types in 2007 and 2008 (mean \pm SD; $n=3$ ). Significant differences between years are shown; $* *=p<$ $0.01 ; *=p<0.05$.

Lund et al., 2010). Also, the area-integrated estimate for nongrowing season ER $\left(77 \mathrm{~g} \mathrm{C} \mathrm{m}^{-2}\right)$ falls within the wide range of previous estimates on cumulative wintertime ER from 1 to $104 \mathrm{~g} \mathrm{C} \mathrm{m}^{-2}$ (Zimov et al., 1996; Heikkinen et al., 2002; Oechel et al., 1997, 2000; Elberling, 2007; Kutzbach et al., 2007b; Vogel et al., 2009).

\subsection{Differences in landscape-scale $\mathrm{CO}_{2}$ fluxes between the two measuring techniques}

Previous tundra $\mathrm{CO}_{2}$ studies combining EC and chamber measurements are strikingly few (Table 6). This study demonstrates the suitability of this kind of nested study design for flux studies in heterogenous environments like tundra. The two methods resulted in very similar $\mathrm{CO}_{2}$ balances for the growing season. However, the area-integrated plotscale measurements showed lower amplitude of the seasonal NEE cycle, and partitioning of the EC fluxes into ER and GP components revealed that the chamber-based $\mathrm{CO}_{2}$ fluxes were lower to both directions. Further, chambers showed a slightly longer net uptake period than EC. Due to these differences, the plot-scale measurements resulted in a significant $\mathrm{CO}_{2}$ sink for the $\mathrm{EC}$ measuring period from May to 
October, while the $\mathrm{CO}_{2}$ balance from EC was also negative but did not differ significantly from zero.

A key reason for the differences between the methods is that the chamber fluxes used for the areal integration were modeling results whereas NEE from EC were mostly obtained by direct measurements. A feature of all models is that they are dominated by the data in the middle of the data range and tend to filter out the extremes. This has implications also for determination of the timing and length of the summer net uptake period. Here, more frequent measurements of LAI and fluxes during spring and autumn would have been helpful.

There are some problems related with the closed chamber technique that may cause underestimation of the gas flux, such as reduction of the concentration gradient between the soil and the atmosphere (Kutzbach et al., 2007a) or underestimation of the effective chamber volume when the air-filled soil pore space is not accounted for (Rayment, 2000). We took care of all necessary precautions to avoid chamber bias: the incubation time was kept short, and fluxes were calculated using non-linear regression. In turn, a known problem of the open path EC gas analyzer is overestimation of $\mathrm{C}$ uptake during the cold season due to heating of the sensor head (e.g., Goulden et al., 2006; Ono et al., 2008). Also, in this study a spring uptake up to $0.5 \mathrm{~g} \mathrm{C} \mathrm{m}^{-2} \mathrm{~d}^{-1}$ was observed while the landscape was still covered by snow, and the correction suggested by Burba et al. (2008) was applied on the data. Since the sensible heat flux in the optical path was not directly measured, the correction was based on the measured air temperature (Burba et al., 2008; Method 4). This may have caused overcorrection of the fluxes (Wohlfahrt et al., 2008; Bowling et al., 2010).

Biased selection of chamber plots (see Fox et al., 2008) or a failure to estimate correctly the coverage of different land cover types would also affect the flux estimates, particularly when the spatial variability in $\mathrm{CO}_{2}$ fluxes is so high. In our study, we found a good match in LAI values between the chamber plots and the corresponding land cover types as a whole, showing that the chamber plots were well representative for the study region. Further, we can be sure that our QuickBird-based land cover classification represented better the small-scale variability in the patchy tundra vegetation than the previously used Landsat image classifications (Soegaard et al., 2000; Heikkinen et al., 2004). While the size of one Landsat image pixel is $900 \mathrm{~m}^{2}$, the mean patch size of homogenous vegetation in this study was $816 \mathrm{~m}^{2}$, the average fen patch being only $260 \mathrm{~m}^{2}$.

\subsection{Regional $\mathrm{CO}_{2}$ balance}

The regional $\mathrm{CO}_{2}$ balance of the tundra area of $98.6 \mathrm{~km}^{2}$ was obtained by upscaling the plot-scale measurements using two independent approaches. From October 2007 to October 2008, the studied tundra acted as a $\mathrm{CO}_{2}$ sink of -79 to $-41 \mathrm{~g} \mathrm{C} \mathrm{m}^{-2} \mathrm{yr}^{-1}$. The gross $\mathrm{CO}_{2}$ fluxes $(\mathrm{GP}=-294$ to
$-238 \mathrm{~g} \mathrm{C} \mathrm{m}^{-2} \mathrm{yr}^{-1}$ and $\mathrm{ER}=197$ to $212 \mathrm{~g} \mathrm{C} \mathrm{m}^{-2} \mathrm{yr}^{-1}$ ) were relatively large compared with the earlier studies summarized in Table 6. This could be due to the milder climatic conditions prevailing in the southern East-European tundra compared with high arctic and more continental sites (see Zamolodchikov and Karelin, 2001). In addition to large-scale variability driven by climate, large site-specific differences exist even within climatic zones. Lowlands with wet soils typically have higher $\mathrm{C}$ accumulation rates than upland tundra in the same region (Table 6; e.g., Vourlitis et al., 2000; Kwon et al., 2006), which is also seen as intrasite variability in this study.

The dependence of $\mathrm{CO}_{2}$ on vascular LAI, discussed above, would provide a more generic explanation for the variability in $\mathrm{CO}_{2}$ budgets in Table 6: The relatively high gross $\mathrm{CO}_{2}$ fluxes at the Seida site could be related to high above-ground biomass compared with the reference studies. Although this hypothesis cannot be verified here since many of the reference studies do not provide data on LAI or biomass, there is published evidence on the potential of LAI to explain variability in $\mathrm{CO}_{2}$ balance even across climatic zones (Lund et al., 2010).

The $\mathrm{C}$ budgets of northern ecosystems also show very large year-to-year fluctuation due to variability in local weather conditions (Table 6; Aurela et al., 2004; Groendahl et al., 2007; Lafleur and Humphreys, 2008; Lund et al., 2010, 2012). The two study years were warmer than the long-term mean, and particularly high temperatures were measured in July during the intensive growth period $\left(3-5^{\circ} \mathrm{C}\right.$ higher than the long-term mean). This probably enhanced both flux components, GP and ER.

Importance of a specific land cover type for the regional $\mathrm{CO}_{2}$ balance is a result of two factors: total coverage in the landscape and magnitude of the $\mathrm{CO}_{2}$ fluxes per unit area. For example, the willow stands that cover only $8.7 \%$ of the study region contributed to the growing season net $\mathrm{CO}_{2}$ uptake by $27 \%$, being as important for the regional balance as the dominant land cover types, tundra bog and shrub tundra heath. The willows with high $\mathrm{C}$ sink capacity may become even more important with future warming, as suggested by the trend of increased willow growth observed in the region during the last decades (Forbes et al., 2010). Studies from northern Alaska show that also deciduous shrubs, dominant in upland tundra, will benefit from warmer temperatures (Tape et al., 2006). The positive dependence observed between LAI and NEE suggests that better growth of vascular plants would mean increased net $\mathrm{C}$ sink to the studied tundra ecosystem, at least in the short term, before the increased respiration due to soil C mobilization takes over as has been predicted (e.g., Qian et al., 2010).

An example of the changes expected in the landscape composition in the future is that the coverage of fen type peatlands will likely increase at the expense of peat plateaus with permafrost thawing (e.g., Johansson et al., 2006). This would increase the $\mathrm{C}$ uptake at regional scale because of the higher 
$\mathrm{CO}_{2}$ sink character of fens. In general, landscape reorganization will have a strong influence on regional $\mathrm{CO}_{2}$ balance in the study region due to the large differences in $\mathrm{CO}_{2}$ balance between different tundra surfaces.

\section{Supplementary material related to this article is

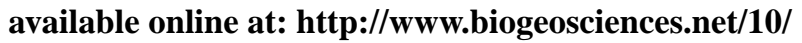 437/2013/bg-10-437-2013-supplement.pdf.}

Acknowledgements. We want to thank the following people for their contribution in the field work and data analysis: Petr Ievlev, Simo Jokinen, Saara Lind, Igor Marushchak, Aleksander Novakovsky, Irina Samarina, Vladimir Shchanov and Tatiana Trubnikova (plot-scale measurements); Anders Anker Bjoerk, Tobias Diaoli, Thomas Grelle, Mathias Herbst, Rasmus Jensen, Theis Schmidt Knudsen, Daniel Grube Pedersen and Jens Bjerg Bertelsen Sand (EC measurements); and Malin Ek, Tiina Ronkainen and Sanna Susiluoto (vegetation and remote sensing data). This study belongs to the EU 6th Framework Programme project CARBO-North (contract number 036993; www.carbonorth.net). M. E. Marushchak received personal funding from the Finnish Graduate School of Forest Sciences. I. Kiepe received funding by the Danish Council for Independent ResearchNatural Sciences (FNU) (Reference number: 645-06-0493).

Edited by: R. Conant

\section{References}

Aubinet, M., Grelle, A., Ibrom, A., Rannik, U., Moncrieff, J., Foken, T., Kowalski, A. S., Martin, P., Berbigier, P., Bernhofer, C., Clement, R., Elbers, J., Granier, A., Grunwald, T., Morgenstern K., Pilegaard, K., Rebmann, C., Snijders, W., Valentini, R., and Vesala, T.: Estimates of the annual net carbon and water exchange of forests: The EUROFLUX methodology, Adv. Ecol. Res., 30, 113-175, doi:10.1016/S0065-2504(08)60018-5, 2000.

Aurela, M., Laurila, T., and Tuovinen, J.: The timing of snow melt controls the annual $\mathrm{CO}_{2}$ balance in a subarctic fen, Geophys. Res. Lett., 31, L16119, doi:10.1029/2004GL020315, 2004.

Bäckstrand, K., Crill, P. M., Jackowicz-Korczyñski, M., Mastepanov, M., Christensen, T. R., and Bastviken, D.: Annual carbon gas budget for a subarctic peatland, Northern Sweden, Biogeosciences, 7, 95-108, doi:10.5194/bg-7-95-2010, 2010.

Baldocchi, D.: Assessing the eddy covariance technique for evaluating carbon dioxide exchange rates of ecosystems: past, present and future, Global Change Biol., 9, 479-492, doi:10.1046/j.1365-2486.2003.00629.x, 2003.

Bazilevich, N. I.: Biological productivity of ecosystems of Northern Eurasia, Nauka, Moscow, 10-22, 1993.

Bowling, D. R., Bethers-Marchetti, S., Lunch, C. K., Grote, E. E., and Belnap, J.: Carbon, water, and energy fluxes in a semiarid cold desert grassland during and following multiyear drought, J. Geophys. Res., 115, G04026, doi:10.1029/2010JG001322, 2010.

Bubier, J. L., Frolking, S., Crill, P. M., and Linder, E.: Net ecosystem productivity and its uncertainty in a diverse bo- real peatland, J. Geophys. Res.-Biogeosci., 104, 27683-27692, doi:10.1029/1999JD900219, 1999.

Burba, G. G., McDermitt, D. K., Grelle, A., Anderson, D. J., and $\mathrm{Xu}, \mathrm{L} .:$ Addressing the influence of instrument surface heat exchange on the measurements of $\mathrm{CO}_{2}$ flux from open-path gas analyzers, Global Change Biol., 14, 1854-1876, doi:10.1111/j.1365-2486.2008.01606.x, 2008.

Christensen, T. R., Friborg, T., Sommerkorn, M., Kaplan, J., Illeris, L., Soegaard, H., Nordstroem, C., and Jonasson, S.: Trace gas exchange in a high-arctic valley 1 , Variations in $\mathrm{CO}_{2}$ and $\mathrm{CH}_{4}$ flux between tundra vegetation types, Global Biogeochem. Cycles, 14, 701-713, doi:10.1029/1999GB001134, 2000.

Corradi, C., Kolle, O., Walter, K., Zimov, S. A., and Schulze, E.-D.: Carbon dioxide and methane exchange of a north-east Siberian tussock tundra, Global Change Biol., 11, 1910-1925, doi:10.1111/j.1365-2486.2005.01023.x, 2005.

Dorrepaal, E., Toet, S., van Logtestijn, R. S. P., Swart, E., van de Weg, M. J., Callaghan, T. V., and Aerts, R.: Carbon respiration from subsurface peat accelerated by climate warming in the subarctic, Nature, 460, 616-619, doi:10.1038/nature08216, 2009.

Elberling, B.: Annual soil $\mathrm{CO}_{2}$ effluxes in the High Arctic: The role of snow thickness and vegetation type, Soil Biol. Biochem., 39, 646-654, doi:10.1016/j.soilbio.2006.09.017, 2007.

Falge, E., Baldocchi, D., Olson, R., Anthoni, P., and Aubinet, M.: Gap filling strategies for defensible annual sums of net ecosystem exchange, Agr. For. Meteorol., 107, 43-69, doi:10.1016/S01681923(00)00225-2, 2001.

Foken T., Göckede, M., Mauder, M., Mahrt, L., Amiro, B., and Munger, W.: Post-field data quality control, in Handbook of Micrometeorology, edited by: Lee, X., Massman, W., and Law, B., Springer, Berlin, Heidelberg, New York, 181-208, 2004.

Forbes, B. C., Macias Fauria, M., and Zetterberg, P.: Russian Arctic warming and "greening" are closely tracked by tundra shrub willows, Global Change Biol., 16, 1542-1554, doi:10.1111/j.13652486.2009.02047.x, 2010.

Fox, A. M., Huntley, B., Lloyd, C. R., Williams, M., and Baxter, R.: Net ecosystem exchange over heterogeneous Arctic tundra: Scaling between chamber and eddy covariance measurements, Global Biogeochem. Cycles, 22, GB2027, doi:10.1029/2007GB003027, 2008.

Fuchs, H., Magdon, P., Kleinn, C., and Flessa, H.: Estimating aboveground carbon in a catchment of the Siberian forest tundra: Combining satellite imagery and field inventory, Remote Sens. Environ., 113, 518-531, doi:10.1016/j.rse.2008.07.017, 2009.

Gash, J. H. C.: A note on estimating the effect of a limited fetch on micrometeorological evaporation measurements, Bound.-Layer Meteorol., 35, 409-413, 1986.

Goulden, M. L., Winston, G. C., McMillan, A. M. S., Litvak, M. E., Read, E. L., Rocha, A. V., and Elliot, J. R.: An eddy covariance mesonet to measure the effect of forest age on landatmosphere exchange, Global Change Biol., 12, 2146-2162, doi:10.1111/j.1365-2486.2006.01251.x, 2006.

Groendahl, L., Friborg, T., and Soegaard, H.: Temperature and snow-melt controls on interannual variability in carbon exchange in the high Arctic, Theor. Appl. Climatol., 88, 111-125, doi:10.1007/s00704-005-0228-y, 2007.

Harazono, Y., Mano, M., Miyata, A., Zulueta, R., and Oechel, W. Inter-annual carbon dioxide uptake of a wet sedge tundra ecosystem in the Arctic, Tellus B, 55, 215-231, doi:10.1034/j.1600- 
0889.2003.00012.x, 2003.

Heikkinen, J. E. P., Elsakov, V., and Martikainen, P. J.: Carbon dioxide and methane dynamics and annual carbon balance in tundra wetland in NE Europe, Russia, Global Biogeochem. Cy., 16, 1115, doi:10.1029/2002GB001930, 2002.

Heikkinen, J. E. P., Virtanen, T., Huttunen, J. T., Elsakov, V., and Martikainen, P. J.: Carbon balance in East European tundra, Global Biogeochem. Cy., 18, GB1023, doi:10.1029/2003GB002054, 2004.

Hugelius, G., Virtanen, T., Kaverin, D., Pastukhov, A., Rivkin, F., Marchenko, S., V. Romanovsky, and P. Kuhry: Highresolution mapping of ecosystem carbon storage and potential effects of permafrost thaw in periglacial terrain, European Russian Arctic, J. Geophys. Res.-Biogeosci., 116, G03024, doi:10.1029/2010JG001606, 2011.

Humphreys, E. R., Lafleur, P. M., Flanagan, L. B., Hedstrom, N., Syed, K. H., Glenn, A. J., and Granger, R.: Summer carbon dioxide and water vapor fluxes across a range of northern peatlands. J. Geophys. Res.-Biogeo., 111, G04011, doi:10.1029/2005JG000111, 2006.

Hutsch, B., Augustin, J., and Merbach, W.: Plant rhizodeposition - an important source for carbon turnover in soils, Z. Pflanzenernähr. Bodenk., 165, 397-407, doi:10.1002/15222624(200208)165:4;397::AID-JPLN397;3.0.CO;2-C, 2002.

Johansson, T., Malmer, N., Crill, P. M., Friborg, T., Akerman, J. H., Mastepanov, M., and Christensen, T. R.: Decadal vegetation changes in a northern peatland, greenhouse gas fluxes and net radiative forcing, Global Change Biol., 12, 2352-2369, doi:10.1111/j.1365-2486.2006.01267.x, 2006.

Kattsov, V. M., Källén, E., Cattle, H., Christensen, J., Drange, H., Hanssen-Bauer, I., Jóhannesen, T., Karol, I., Räisänen, J., Svensson, G, and Vavulin, S.: Future climate change: Modeling and scenarios for the Arctic, in Arctic Climate Impact Assessment, edited by: Symon, C., Arris, L., and Heal, B., Cambridge University Press, New York, 99-150, 2005.

Kutzbach, L., Schneider, J., Sachs, T., Giebels, M., Nykanen, H., Shurpali, N. J., Martikainen, P. J., Alm, J., and Wilmking, M.: $\mathrm{CO}_{2}$ flux determination by closed-chamber methods can be seriously biased by inappropriate application of linear regression, Biogeosciences, 4, 1005-1025, doi:10.5194/bgd-4-2279-2007, 2007a.

Kutzbach, L., Wille, C., and Pfeiffer, E.-M.: The exchange of carbon dioxide between wet arctic tundra and the atmosphere at the Lena River Delta, Northern Siberia, Biogeosciences, 4, 869-890, doi:10.5194/bg-4-869-2007, 2007b.

Kwon, H., Oechel, W. C., Zulueta, R. C., and Hastings, S. J.: Effects of climate variability on carbon sequestration among adjacent wet sedge tundra and moist tussock tundra ecosystems, J. Geophys. Res.-Biogeosci., 111, G03014, doi:10.1029/2005JG000036, 2006.

Lafleur, P. M. and Humphreys, E. R.: Spring warming and carbon dioxide exchange over low Arctic tundra in central Canada, Global Change Biol., 14, 740-756, doi:10.1111/j.13652486.2007.01529.x, 2008.

Laidler, G. J. and Treitz, P.: Biophysical remote sensing of arctic environments, Prog. Phys. Geogr., 27, 44-68, doi:10.1191/0309133303pp358ra, 2003.

Lloyd, C. R.: On the physical controls of the carbon dioxide balance at a high Arctic site in Svalbard, Theor. Appl. Climatol., 70, 167-
182, doi:10.1007/s007040170013, 2001

Lloyd, J. and Taylor, J. A.: On the temperature-dependence of soil respiration, Funct. Ecol., 8, 315-323, 1994.

Lund, M., Lafleur, P. M., Roulet, N. T., Lindroth, A., Christensen, T. R., Aurela, M., Chojnicki, B. H., Flanagan, L. B., Humphreys, E. R., Laurila, T., Oechel, W. C., Olejnik, J., Rinne, J., Schubert, P., and Nilsson, M. B.: Variability in exchange of $\mathrm{CO}_{2}$ across 12 northern peatland and tundra sites, Global Change Biol., 16, 2436-2448, doi:10.1111/j.1365-2486.2009.02104.x, 2010.

Lund, M., Falk, J. M., Friborg, T., Mbufong, H. N., Sigsgaard, C., Soegaard, H., and Tamstorf, M. P.: Trends in $\mathrm{CO}_{2}$ exchange in a high Arctic tundra heath, 2000-2010, J. Geophys. Res., 117, G02001, doi:10.1029/2011JG001901, 2012.

Marushchak, M. E., Pitkämäki, A., Koponen, H., Biasi, C., Seppälä, M., and Martikainen, P. J.: Hot spots for nitrous oxide emissions found in different types of permafrost peatlands, Global Change Biol., 17, 2601-2614, doi:10.1111/j.1365-2486.2011.02442.x, 2011.

McFadden, J. P., Eugster, W., and Chapin, F. S.: A regional study of the controls on water vapor and $\mathrm{CO}_{2}$ exchange in arctic tundra, Ecology, 84, 2762-2776, doi:10.1890/01-0444, 2003.

Merbold, L., Kutsch, W. L., Corradi, C., Kolle, O., Rebmann, C., Stoy, P. C., Zimov, S. A., and Schulze, E.-D.: Artificial drainage and associated carbon fluxes $\left(\mathrm{CO}_{2} / \mathrm{CH}_{4}\right)$ in a tundra ecosystem, Global Change Biol., 15, 2599-2614, doi:10.1111/j.13652486.2009.01962.x, 2009.

Moncrieff, J., Massheder, J., deBruin, H., Elbers, J., Friborg, T., Heusinkveld, B., Kabat, P., Scott, S., Soegaard, H., and Verhoef, A.: A system to measure surface fluxes of momentum, sensible heat, water vapour and carbon dioxide, J. Hydrology, 189, 589611, doi:10.1016/S0022-1694(96)03194-0, 1997.

Nordstroem, C., Soegaard, H., Christensen, T. R., Friborg, T., and Hansen, B. U.: Seasonal carbon dioxide balance and respiration of a high-arctic fen ecosystem in NE-Greenland, Theor. Appl. Climatol., 70, 149-166, doi:10.1007/s007040170012, 2001.

Nykänen, H., Alm, J., Lång, K., Silvola, J., and Martikainen, P. J.: Emissions of $\mathrm{CH}_{4}, \mathrm{~N}_{2} \mathrm{O}$ and $\mathrm{CO}_{2}$ from a virgin fen and a fen drained for grassland in Finland, J. Biogeogr., 22, 351-357, doi:10.1016/S1161-0301(97)00036-1, 1995.

Oechel, W., Vourlitis, G., and Hastings, S.: Cold season $\mathrm{CO}_{2}$ emission from arctic soils, Global Biogeochem. Cy., 11, 163-172, doi:10.1029/96GB03035, 1997.

Oechel, W. C., Vourlitis, G. L., Verfaillie Jr., J., Crawford, T., Brooks, S., Dumas, E., Hope, A., Stow, D., Boynton, B., Nosov, V., and Zulueta, R.: A scaling approach for quantifying the net $\mathrm{CO}_{2}$ flux of the Kuparuk River Basin, Alaska, Global Change Biol., 6, 160-173, doi:10.1046/j.1365-2486.2000.06018.x, 2000.

Ono, K., Miyata, A., and Yamada, T.: Apparent downward $\mathrm{CO}_{2}$ flux observed with open-path eddy covariance over a non-vegetated surface, Theor. Appl. Climatol., 92, 195-208, doi:10.1007/s00704-007-0323-3, 2008.

Parmentier, F. J. W., van der Molen, M. K., van Huissteden, J., Karsanaev, S. A., Kononov, A. V., Suzdalov, D. A., Maximov, T. C., and Dolman, A. J.: Longer growing seasons do not increase net carbon uptake in the northeastern Siberian tundra, J. Geophys. Res., 116, G04013, doi:10.1029/2011JG001653, 2011.

Pihlatie, M. K., Kiese, R., Brüggemann, N., Butterbach-Bahl, K., Kieloaho, A.-J., Laurila, T., Lohila, A., Mammarella, I., Minkkinen, K., Penttilä, T., Schönborn, J., and Vesala, T.: Greenhouse 
gas fluxes in a drained peatland forest during spring frost-thaw event, Biogeosciences, 7, 1715-1727, doi:10.5194/bg-7-17152010, 2010.

Qian, H., Joseph, R., and Zeng, N.: Enhanced terrestrial carbon uptake in the Northern High Latitudes in the 21st century from the Coupled Carbon Cycle Climate Model Intercomparison Project model projections, Global Change Biol., 16, 641-656, doi:10.1111/j.1365-2486.2009.01989.x, 2010.

Rayment, M.: Closed chamber systems underestimate soil $\mathrm{CO}_{2}$ efflux, Eur. J. Soil Sci., 51, 107-110, doi:10.1046/j.13652389.2000.00283.x, 2000.

Reichstein, M., Falge, E., Baldocchi, D., Papale, D., Aubinet, M., Berbigier, P., Bernhofer, C., Buchmann, N., Gilmanov, T., Granier, A., Grünwald, T., Havránková, K., Ilvesniemi, H., Janous, D., Knohl, A., Laurila, T., Lohila, A., Loustau, D., Matteucci, G., Meyers, T., Miglietta, F., Ourcival, J.-M., Pumpanen, J., Rambal, S., Rotenberg, E., Sanz, M., Tenhunen, J., Seufert, G., Vaccari, F, Vesala, T., Yakir, D., and Valentini, R.: On the separation of net ecosystem exchange into assimilation and ecosystem respiration: review and improved algorithm, Global Change Biol., 11, 1424-1439, doi:10.1111/j.1365-2486.2005.001002.x, 2005.

Repo, M. E., Huttunen, J. T., Naumov, A. V., Chichulin, A. V., Lapshina, E. D., Bleuten, W., and Martikainen, P. J.: Release of $\mathrm{CO}_{2}$ and $\mathrm{CH}_{4}$ from small wetland lakes in western Siberia, Tellus B, 59, 788-796, doi:10.1111/j.1600-0889.2007.00301.x, 2007.

Schuepp, P. H., Leclerc, M. Y., Macpherson, J. I., and Desjardins, R. J.: Footprint predictions of scalar fluxes from analytical solutions of the diffusion equation, Bound.-Lay. Meteorol., 50, 355-373, doi:10.1007/BF00120530, 1990.

Schuur, E. A. G., Vogel, J. G., Crummer, K. G., Lee, H., Sickman, J. O., and Osterkamp, T. E.: The effect of permafrost thaw on old carbon release and net carbon exchange from tundra, Nature, 459, 556-559, doi:10.1038/nature08031, 2009.

Shaver, G. R., Johnson, L., Cades, D., Murray, G., Laundre, J., Rastetter, E., Nadelhoffer, K., and Giblin, A.: Biomass and $\mathrm{CO}_{2}$ flux in wet sedge tundras: Responses to nutrients, temperature, and light, Ecol. Monogr., 68, 75-97, 1998.

Shaver, G. R., Street, L. E., Rastetter, E. B., Van Wijk, M. T., and Williams, M.: Functional convergence in regulation of net $\mathrm{CO}_{2}$ flux in heterogeneous tundra landscapes in Alaska and Sweden, J. Ecol., 95, 802-817, doi:10.1111/j.1365-2745.2007.01259.x, 2007.

Soegaard, H., Nordstroem, C., Friborg, T., Hansen, B. U., Christensen, T. R., and Bay C.: Trace gas exchange in a higharctic valley. 3. Integrating and scaling $\mathrm{CO}_{2}$ fluxes from canopy to landscape using flux data, footprint modeling, and remote sensing, Global Biogeochem. Cy., 14, 725-744, doi:10.1029/1999GB001137, 2000.

Soegaard, H., Jensen, N. O., Boegh, E., Hasager, C. B., Schelde, K., and Thomsen, A.: Carbon dioxide exchange over agricultural landscape using eddy correlation and footprint modelling, Agric. For. Meteorol., 114, 153-173, doi:10.1016/S01681923(02)00177-6, 2003.
Tape, K., Sturm, M., and Racine, C.: The evidence for shrub expansion in Northern Alaska and the Pan-Arctic, Global Change Biol., 12, 686-702, doi:10.1111/j.1365-2486.2006.01128.x, 2006.

Tarnocai, C., Canadell, J. G., Schuur, E. A. G., Kuhry, P., Mazhitova, G., and Zimov, S.: Soil organic carbon pools in the northern circumpolar permafrost region, Global Biogeochem. Cy., 23, GB2023, doi:10.1029/2008GB003327, 2009.

van der Molen, van Huissteden, M. K., J., Parmentier, F. J. W., Petrescu, A. M. R., Dolman, A. J., Maximov, T. C., Kononov, A. V., Karsanaev, S. V., and Suzdalov, D. A.: The growing season greenhouse gas balance of a continental tundra site in the Indigirka lowlands, NE Siberia, Biogeosciences, 4, 985-1003, doi:10.5194/bg-4-985-2007, 2007.

Vogel, J., Schuur, E. A. G., Trucco, C., and Lee, H.: Response of $\mathrm{CO}_{2}$ exchange in a tussock tundra ecosystem to permafrost thaw and thermokarst development, J. Geophys. Res.-Biogeosciences, 114, G04018, doi:10.1029/2008JG000901, 2009.

Vourlitis, G. L. and Oechel, W. C.: Landscape-scale $\mathrm{CO}_{2}, \mathrm{H}_{2} \mathrm{O}$ vapour and energy flux of moist-wet coastal tundra ecosystems over two growing seasons, J. Ecol., 85, 575-590, 1997.

Vourlitis, G., Harazono, Y., Oechel, W., Yoshimoto, M., and Mano, M.: Spatial and temporal variations in hectare-scale net $\mathrm{CO}_{2}$ flux, respiration and gross primary production of Arctic tundra ecosystems, Funct. Ecol., 14, 203-214, doi:10.1046/j.13652435.2000.00419.x, 2000.

Walker, M. D., Wahren, C. H., Hollister, R. D., Henry, G. H. R., Ahlquist, L. E., Alatalo, J. M., Bret-Harte, M. S., Calef, M. P., Callaghan, T. V., Carroll, A. B., Epstein, H. E., Jónsdóttir, I. S., Klein, J. A., Magnússon, B., Molau, U., Oberbauer, S. F., Rewa, S. P., Robinson, C. H., Shaver, G. R., Suding, K., N., Thompson, C. C., Tolvanen, A., Totland, Ø., Turner, P. L., Tweedie, C. E., Webber, P. J., and Wookey, P. A.: Plant community responses to experimental warming across the tundra biome, Proc. Natl. Acad. Sci. USA, 103, 1342-1346, doi:10.1073/pnas.0503198103, 2006.

Wohlfahrt, G., Fenstermaker, L. F., and Arnone, J. A.: Large annual net ecosystem $\mathrm{CO}_{2}$ uptake of a Mojave Desert ecosystem, Global Change Biol., 14, 1475-1487, doi:10.1111/j.13652486.2008.01593.x, 2008.

Zamolodchikov, D. G. and Karelin, D. V.: An empirical model of carbon fluxes in Russian tundra, Global Change Biol., 7, 147161, doi:10.1046/j.1365-2486.2001.00380.x, 2001.

Zamolodchikov, D., Karelin, D., and Ivaschenko, A.: Sensitivity of tundra carbon balance to ambient temperature, Water Air Soil Poll., 119, 157-169, doi:10.1023/A:1005194613088, 2000.

Zamolodchikov, D. G., Karelin, D. V., Ivaschenko, A. I., Oechel, W. C., and Hastings, S. J.: $\mathrm{CO}_{2}$ flux measurements in Russian Far East tundra using eddy covariance and closed chamber techniques, Tellus B, 55, 879-892, doi:10.1046/j.14356935.2003.00074.x, 2003.

Zimov, S., Davidov, S., Voropaev, Y., Prosiannikov, S., Semiletov, I., Chapin, M., and Chapin, F.: Siberian $\mathrm{CO}_{2}$ efflux in winter as a $\mathrm{CO}_{2}$ source and cause of seasonality in atmospheric $\mathrm{CO}_{2}$, Clim. Change, 33, 111-120, 1996. 